Portland State University

PDXScholar

$12-21-2015$

\title{
Dendrochronology and Middle Miocene Petrified Oak: Modern Counterparts and Interpretation
}

\author{
William E. Wright \\ University of Arizona \\ Martin J. Streck \\ Portland State University, streckm@pdx.edu \\ Christopher Baisan \\ University of Arizona \\ W. Walton Wright \\ Paul Szejner \\ University of Arizona
}

Follow this and additional works at: https://pdxscholar.library.pdx.edu/geology_fac

Part of the Geology Commons

Let us know how access to this document benefits you.

\section{Citation Details}

Wright, William E., Baisan, Christopher, Streck, Martin, Walton Wright, W., Szejner, Paul, Dendrochronology and middle Miocene petrified oak: Modern counterparts and interpretation, Palaeogeography, Palaeoclimatology, Palaeoecology (2015), doi: 10.1016/j.palaeo.2015.12.023

This Post-Print is brought to you for free and open access. It has been accepted for inclusion in Geology Faculty Publications and Presentations by an authorized administrator of PDXScholar. Please contact us if we can make this document more accessible: pdxscholar@pdx.edu. 


\section{Accepted Manuscript}

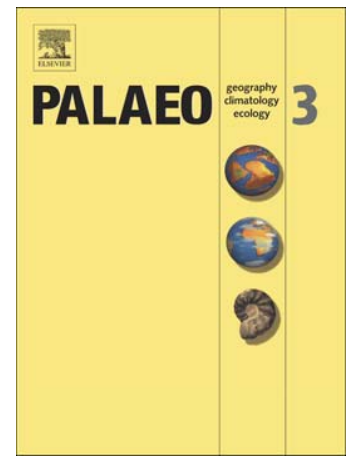

Dendrochronology and middle Miocene petrified oak: Modern counterparts and interpretation

William E. Wright, Christopher Baisan, Martin Streck, W. Walton Wright, Paul Szejner

PII: $\quad$ S0031-0182(15)00749-X

DOI: $\quad$ doi: $10.1016 /$ j.palaeo.2015.12.023

Reference: $\quad$ PALAEO 7624

To appear in: $\quad$ Palaeogeography, Palaeoclimatology, Palaeoecology

Received date: $\quad 18$ April 2015

Revised date: $\quad 14$ December 2015

Accepted date: 21 December 2015

Please cite this article as: Wright, William E., Baisan, Christopher, Streck, Martin, Walton Wright, W., Szejner, Paul, Dendrochronology and middle Miocene petrified oak: Modern counterparts and interpretation, Palaeogeography, Palaeoclimatology, Palaeoecology (2015), doi: 10.1016/j.palaeo.2015.12.023

This is a PDF file of an unedited manuscript that has been accepted for publication. As a service to our customers we are providing this early version of the manuscript. The manuscript will undergo copyediting, typesetting, and review of the resulting proof before it is published in its final form. Please note that during the production process errors may be discovered which could affect the content, and all legal disclaimers that apply to the journal pertain. 
Dendrochronology and middle Miocene petrified oak: modern counterparts and interpretation

William E. Wright ${ }^{\mathrm{a}^{*}}$, Christopher Baisan ${ }^{\mathrm{a}}$, Martin Streck $^{\mathrm{b}}$, W. Walton Wright ${ }^{\mathrm{c}}$, Paul Szejner ${ }^{\mathrm{a}}$

${ }^{a}$ Laboratory of Tree-Ring Research, University of Arizona, Tucson, AZ, 85721, USA

${ }^{\mathrm{b}}$ Department of Geology, Portland State University, Portland, OR, 97201, USA

${ }^{\mathrm{c}}$ Brea, CA, 92821, USA

Corresponding author. Telephone: +1 5206216469 FAX +1 5206218229

Abstract

This study reports the first successful statistical 'crossdating' among many ring width time series from petrified wood, thus providing a replicable continuous annual resolution window into tree growth and environmental influences during the middle Miocene. The petrified samples, of the genus Quercus, originated at the Stinking Water (SW) locality in Oregon, a Miocene-aged exposure associated with the Columbia River Basalts. ${ }^{40} \mathrm{AR} /{ }^{39} \mathrm{AR}$ dating on pillow basalt from the locality yielded a weighted Plateau Age of $13.79 \pm 0.09$ Ma placing the death of the trees at the end of the Langhian Stage of the Middle Miocene (15.97 \pm 0.05 to $13.65 \pm 0.05 \mathrm{Ma})$, during the middle Miocene Climate Transition (MMCT). Ring width time series from 26 radii, 17 different trees, show significant intercorrelation. A Modified Coexistence Approach was applied to determine the likely climate range when the SW trees were growing. The modified approach included regression of site-mean ring width time series statistic values on estimated soil moisture for the site locations, using site-mean data from 126 modern Quercus sites from across the United States. Identification of highly significant linearities indicated strong relationships 
between ring width intercorrelation and soil moisture and ring width variability and soil moisture. Comparison of individual modern site-mean statistical values with values calculated for the SW locality suggests a mesic growing environment for the SW Quercus, with moderate temperatures. Geographic placement of modern Quercus sites with site-mean statistics similar to the SW values indicates a modern analogue in the eastern United States. Modern distributions of mesic species in the genera present at the SW locality suggest similarities with the central and southern Appalachian Mountains and the Ozark/Ouachita Mountains, indicating a mean annual temperature range of $\cong 10{ }^{\circ} \mathrm{C}$ to $\cong 15^{\circ} \mathrm{C}$ and a mean annual precipitation range of $\cong 750 \mathrm{~mm}$ to $\cong 1200 \mathrm{~mm}$ when the SW Quercus were growing.

\section{Introduction}

Many studies of rings in petrified wood have used growth ring related information as indications of environmental conditions present at the time when the trees were growing. The presence of regular growth ring formation has been taken to indicate growth seasonality or paleolatitude (Creber, 1977; Creber and Francis, 1999). Statistical characteristics of the growth rings have been used to determine the average annual radial growth and aspects of the paleoenvironment when the tree was growing, especially the mean ring width (e.g. Creber, 1977; Creber and Chaloner, 1985; Ammons, 1987; Morgans, 1999; Morgans and Hesselbo, 1999; Brison et al., 2001; Falcon-Lang et al, 2004; Taylor and Ryberg, 2007; Brea et al., 2015) and mean sensitivity, a measure of the relationship between tree growth and climate (Ammons, 1987; Morgans, 1999; Morgans and Hesselbo, 1999; Falcon-Lang, 2003; Falcon-Lang et al., 2004; Taylor and Ryberg, 2007; Davies-Vollum et al., 2011; Brea et al., 2015).

Formation of tree rings requires the slowing or cessation of radial tree growth followed by growth increase or resumption. Most tree rings are formed as a response to seasonal changes in 
climate, usually to changes in temperature. The modern causes of ring formation are assumed to have held for the distant past, such that the regular formation of rings in petrified wood is interpreted as evidence of an annual cycle of climatic seasonality (e.g. Creber and Chaloner, 1985). Recognizing the presence of growth rings in petrified wood requires preservation of structural details across the tree's radius, and the degree of preservation in petrified wood varies from almost perfect preservation of the cellular and subcellular features of the xylem to complete loss of all features. Preservation of cellular and subcellular details in petrified wood is thought to require rapid burial under anaerobic conditions (e.g. below the water table), an environment that retards decomposition and allows minerals to precipitate in open spaces in the xylem (Poole et al., 2004).

Accuracy in determining average tree growth characteristics from tree ring widths, and by extension environmental information related to the tree growth/climate relationship, requires estimation of the site mean ring width values (Fritts, 1976, p23), requiring at least some evidence of contemporaneous growth between the wood specimens (Creber and Chaloner, 1985). Further, short ring width time series are unlikely to provide an accurate estimate of the mean growth, because tree ring-width variability within individual trees varies through time. Similarly, interannual variability in the ring width relationships between contemporaneous trees is highly variable, ensuring that time series statistics calculated from ring width measurements on any individual specimen are likely to depart from the theoretical mean for all trees growing at a tree site. An accurate ring width site mean, one that captures a high proportion of the variability in common between the trees, requires ring width information from multiple trees and many rings; the number being dependent on factors such as the genus and the sensitivity of the tree growth to climate change. In addition, some ring width time series statistics (e.g. intercorrelation and 
expressed population signal) require statistical crossdating (e.g. crossmatching) of the ring width time series before they can be calculated.

Can crossdating of ring width time series from petrified wood provide additional or more accurate estimates of growth or climate information? Creber and Chaloner (1987) indicated that crossmatching (crossdating) is not necessary in paleo contexts if the petrified wood is in situ, evidence of contemporaneity, because the intention is to recover a "general indication of the climatic environment". They further state that the paleo wood identity is only being expressed at the generic level, and that therefore "no knowledge of its precise response to the climatic environment is available." Since that time the Coexistence Approach, based on the presence of multiple genera with "nearest living relatives" preserved at the same time at the same site, has been developed to gain more specific information about the growth environments (Mosbrugger and Utescher, 1997; Utescher et al., 2014). If petrified specimens are determined to be preserved in the growth position, and a Coexistence Approach can be applied, then what is to be further gained by crossdating, beyond absolute proof of contemporaneity?

First, crossdating allows identification of a common interannual growth pattern, thereby, providing clear evidence for the climate influence on the tree growth beyond seasonal growth cessation. Ring width statistics calculated on non-crossmatched individual time series will always include an unknown proportion of the ring width variability that is not attributable to climate, thereby overestimating or underestimating the true climate influence on the tree growth. Second, the strength of the crossdating is itself sensitive to climate, and provides additional evidence of the influence of the climate on the tree growth. Third, if enough specimens can be significantly crossdated, then the strength of the common signal can be assessed and compared with a hypothetically perfect mean time series based on an infinite number of trees, a statistic 
called the Expressed Population Signal (EPS; e.g. Cook and Kairiukstis, 1990). The sample depth required to capture an acceptable proportion of the hypothetically perfect common signal can then be determined (Wigley et al, 1987). Any time series statistics calculated using the portion of the crossmatched time series that exceeds the EPS threshold provide the best estimate of the mean values for the entire population. Finally, comparison of site-mean time series statistical values from paleo specimens with the same statistic from for the same genus from many modern sites may indicate modern environments where the tree growth has similar characteristics.

Dendrochronology, the science of "tree time", holds crossdating (crossmatching) of ring width patterns between trees as its most important principle (e.g. Fritts, 1976; Fritts and Swetnam, 1989; Cook and Kariukstis, 1990). Crossdating of tree ring widths provides evidence of a variable inter-annual growth pattern in common between the trees, a pattern that is independent of any longer term trends in growth and establishes the absolute contemporaneity of the crossdated tree rings. Crossdating of tree ring-width time series for environmental assessment is usually quantified statistically, through simple linear regression of the individual ring width time series, with significance being determined using correlation coefficients or t-scores (e.g. Cook and Kairiukstis, 1990). Ring-width time series of 50 to over 200 years (e.g. Sequoia gigantea) are required to reach a statistically significant result that exceeds all spurious matches, with the number of years required being dependent on the amount of interannual variability.

The earliest known attempt at crossdating of ring widths in permineralized wood was reported by Andrew Ellicott Douglass (1936), the astronomer who developed the science of dendrochronology, when he analyzed specimens from Yellowstone National Park, USA. While the methods used by Douglass were theoretically and statistically sound, his study of 
permineralized wood from this site was ultimately unsuccessful. Since then the few studies that have reported absolute contemporeneity based on tree ring width evidence amoung multiple specimens of petrified wood (Ammons et al., 1987; Kumugai and Fukao, 1992) did so without adequate statistical support. Ammons et al. (1987) based their conclusions on visual comparisons of mean ring widths between specimens (which the authors called "ring correlations", language that incorrectly implies regression statistics.) The authors did recognize the need for true crosscorrelation, but did not apply the technique because of "partly-overlapping, relatively short records". Kumugai and Fukao (1992) applied cross-correlation to time series from permineralized wood, but the results were immediately called to question for a lack of appropriate statistical pretreatment of the time series; no detrending and prewhitening (Yamaguchi and Grissino-Mayer, 1993). Detrending and prewhitening are necessary prerequisites to cross-correlation of tree-ring width time series, because low frequency trends of biological origin are present in most tree-ring time series (Fritts, 1976), often resulting in spurious significance in the correlation coefficients. In an excellent recent study, Brea et al. (2015) used what they termed dendrochronological techniques, but their techniques did not include statistical crossmatching, the guiding principle of dendrochronology. In this case crossmatching would not have been possible, because the average number of measured rings per specimen was less than 20. Currently, the only reported crossdating of petrified wood using dendrochronological criteria, including detrending and normalization, is between two specimens out of nine analyzed from the Florissant Fossil Beds National Monument, Colorado (Gregory, 1992). Regression of these specimens yielded a correlation coefficient of $r=0.57$ for a common period of 180 years. 
The study described herein involves application of classic dendrochronological techniques in analyses of Miocene-aged specimens originating at a locality called Stinking Water (SW) at the south end of the Stinking Water Mountains in southeastern Oregon, USA. Deposits at the SW locality are part of widespread but variable Miocene volcanism in eastern Oregon, where lavas associated with the Columbia River Flood Basalt Province are the most voluminous (Camp, 2013; Camp et al., 2013). The SW deposits are correlated with basaltic lavas of the Tba unit of Green et al. (1972), appearing west of the SW fossil locality and overlying rhyolites of the $15-16$ Ma Buchanan dome complex (Large and Streck, manuscript in preparation). The fragmentary nature of the SW basalt, including pillow basalt forms, and the remarkable preservation of the petrified wood, suggests a relatively quiescent interaction with water before encasement of the trees. Entombment of many stems in vertical orientation amoung ash and pillow basalts, with very little deformation during preservation, indicates in situ preservation. The region around the Stinking Water Mountains is known for high quality paleobotanical specimens, including two type locations, Locality P4120 and Locality P4006, where fossil leaves and fruit have been described together as the Stinking Water Flora (Chaney and Axelrod, 1959). The SW petrified wood locality is within 12 kilometers of the type locations, and was included in the same publication as Locality P4007 (Chaney and Axelrod, 1959). Chaney and Axelrod (1959) believed that all three localities were contemporaneous, but their assumption has not yet been verified.

Microscopic inspection of the Stinking Water petrified wood reveals remarkable preservation of the rings and cellular structure of the wood (Fig. 1), allowing clear identification of the tree genera. Dr. Herbert L. Hegert, a chemist and paleobotanist with the forest products company Rayonier, was the first to identify the SW genera, recognizing Quercus, Carya, Ulmus, 
Fraxinus, and Picea (Chaney and Axelrod, 1959). Existence of these genera amoung the SW specimens was confirmed. Additional genera present included Populus, Juniperus, Juglans and Metasequoia. Specimens recovered over the years at the SW locality were dominantly Quercus, with the White Oak group being the most numerous, the Red Oak group only slightly less so.

Fig. 1 190mm (full width)

This study tests three sequential hypotheses. First, can measured ring width time series from the extremely well preserved permineralized Quercus specimens originating at the SW locality be statistically crossmatched? Second, if statistical crossmatching is possible, then is the composite signal strength robust enough to provide reliable information about site-mean measures of radial growth? Third, if the site-mean radial growth can be reliably estimated, then can characteristics of the Miocene paleo-environment at the SW locality be estimated by comparing the SW ring width time series statistics with the same statistics from modern Quercus?

\section{Materials and Methods}

\subsection{Materials}

The SW permineralized wood locality is in east central Oregon at the south end of the Stinkingwater Mountains. A 1984 newspaper interview of a resident who visited the site in 1938 indicates that there were many vertical stems at that time extending 2-5 feet $(0.6-1.5 \mathrm{~m})$ above the entombing volcanics (Allen, 1984). All easily accessible specimens had been removed by the mid-1960s (Gail, 1967), but cut and polished petrified wood specimens from the SW locality are 
on display at various museums, can be found in many private collections and are often offered for sale at gem and mineral shows. Sources of the SW specimens for this study included the Herb Zuhl Museum at New Mexico State University in Las Cruces, New Mexico, the Rice Northwest Museum of Rocks and Minerals in Hillsboro, Oregon, and private collectors and dealers who agreed to bring specimens to the 2013 and 2014 Tucson Gem and Mineral Shows, in Tucson, Arizona, USA.

Most of the samples examined during this study came from sections of stems removed in later years from below the current ground surface, and, according to the collectors who recovered some of the specimens or witnessed the recovery, this sometimes involved removal of the permineralized stems to a depth of up to 3 meters. Interviews and photographic evidence indicate that the specimens were removed vertically from the volcanic layer through the original holes formed by the tree stems during their entombment, using tripods and block and tackle or similar equipment. The current depth from the surface to the original Miocene forest floor ranges from zero, in areas where root boles are in evidence, to as much as 4 meters. All the specimens measured in this study had been cut along the transverse plane (cross-section) and were highly polished. Cut and polished samples from the SW locality are generally recognizable to the trained eye, by their characteristic coloration and lack of deformation, and by the remarkable preservation of cellular and even subcellular details (Fig. 1).

\subsection{Methods}

\subsubsection{Sample Identification and Processing}

The genus Quercus was identified from amoung the SW specimens based on characteristics visible on the transverse surface, including a ring porous architecture and the 
presence of both wide and narrow rays (uniseriate and multi-seriate; e.g. Esau, 1960, Hoadley, 1990). Specimens from both the Red Oak and White Oak groups are in evidence among the Stinking Water specimens, a categorization dependent on the number of tyloses in the earlywood vessels of the heartwood (few to none in the Red Oak group, abundant in the White Oak group) and the size of vessels in the latewood (abrupt transition to small vessels in the White Oak Group) (e.g. Esau, 1960, Hoadley, 1990). Members of the Red Oak and White Oak groups are commonly found growing together in modern settings and apparently have similar responses to climate (e.g. LeBlanc and Therrell, 2011).

A few specimens identified as live oak (evergreen oak) have also been recovered from the SW locality. Unlike most Quercus, live oaks are diffuse porous, with solitary vessels in roughly linear arrangement along the cell files. The rays are both uniseriate and multiseriate, with a clear separation in the widths of the two groups, and the growth ring banding is indistinct (Hoadley, 1990). Distinguishing the tree ring boundaries in the permineralized specimens of live oak was not possible because of the indistinct growth rings.

Ring widths on each specimen, a total of 26 time series from 17 different Quercus stems (trees), were measured to a resolution of $0.001 \mathrm{~mm}$ on one or sometimes two radii using either Henson ${ }^{\circledR}$ or Velmex UniSlide ${ }^{\circledR}$ measuring stages. Ring width measurements were made at the Laboratory of Tree-Ring Research, Tucson, Arizona, at the museums, or at the homes of the collectors. Most of the SW specimens analyzed for this study are currently in the possession of museums, researchers, collectors and dealers.

\subsubsection{Statistics and Climate data}


Common patterns between the SW ring-widths were investigated through visual comparisons and then through regression of the ring width time series. Statistical crossdating was confirmed using COFECHA (Holmes, 1983). From this point forward the term "crossmatching" is used in this manuscript instead of "crossdating" when referring to the SW samples, because a calendar year can never be assigned to the match. "Crossmatching" therefore refers to statistically significant non-spurious correlation coefficients from regressions amoung detrended SW ring width time series.

Chronology production proceeded by detrending the raw ring width time series using a smoothing spline with a 0.50 frequency response at a wavelength of $67 \%$ of the series length (Cook and Peters, 1981) followed by calculation of Tukey's biweight robust mean (Mosteller and Tukey, 1977) when combining the time series. Fig. 2 presents a 252 -year mean ring width master time series (or chronology) produced from twenty six individual time series and an EPS assessment of signal strength from seventeen tree-mean time series.

Fig. 2 190mm (full width)

Ring width time series from 126 modern Quercus sites in the United States were obtained from data archived at the International Tree Ring DataBank (http://www.ncdc.noaa.gov/paleo/treering.html). The species of Quercus used in this analysis are those most often sampled for dendrochronological studies in the United States include Q. alba, Q. prinus, Q. douglasii, Q. stellata, and $Q$. rubra. Sites with mean sample ages of less than 100 years were not included to ensure that the comparison was done using data from mature trees. The crossmatching of each modern Quercus site was verified using COFECHA (Holmes, 1983). 
Site-mean ring width was determined for each location and the time series were then detrended as described for the SW time series prior to calculation of additional time series statistics.

Statistics applied to ring width time series can inform about different aspects of tree growth for individual trees and for the tree site; (1) average growth, (2) interannual growth variability, (3) the influence of prior growth on current growth, and (4) the strength of the common interannual pattern between trees. The statistics used to measure these different aspects of tree growth based on ring widths are (1) the mean ring width, (2) the mean interannual ring width variability, (3) the mean ring width autocorrelation (the influence of prior growth on current growth), and (4) the mean ring width intercorrelation. Calculating the average tree age at each site is also useful to ensure that comparisons between sites are made between similar-aged stands of trees. In addition, the $2 \sigma$ values for each statistic provide a valuable tool for comparison between site-mean values and the range of values for the individual time series. The following time series statistics were calculated for the SW time series and the time series from the 126 modern Quercus sites.

Site-mean tree age $(\overline{y r})$ was determined based on the number of rings on the longest time series for each tree. Modern Quercus sites with mean tree ages less than 100 years were excluded from the analysis to ensure that only time series from stands of mature trees were analyzed.

Site-mean ring width $(\overline{r w})$ is the average of the tree-mean ring width for all the trees at a site, prior to any statistical modification. Mean ring width calculated for one time series indicates the average radial growth for that radius on an individual tree. With enough trees sampled, $\overline{r w}$ can indicate the average radial growth at the tree site. 
Site-mean interannual ring width variability was calculated using three statistics, mean sensitivity $(\bar{\zeta})$, standard deviation $(\bar{\sigma})$ and Gini coefficient $(\bar{G})$. Mean sensitivity $(\zeta)$ is often interpreted as indicating the influence of climate on radial growth. The close relationship between $\zeta$ and ring width standard deviation $(\sigma)$ has been discussed for many years (e.g. Fritts, 1976, p. 395; Fritts et al., 1965, Fig. 6.18), and there have been calls for reconsidering the use of $\zeta$, by substituting the Gini coefficient (Biondi and Qeadan, 2008) or the ring width standard deviation (Bunn et al., 2013; Strackee and Jansma, 1992) based on statistical evidence that standard deviation $(\sigma)$ and first order autocorrelation $(\phi)$ accurately decompose $\zeta$, with $\sigma$ being proportional to $\zeta$ (Bunn et al., 2013). Consequently, we have chosen to present the ring width interannual variability results using $\zeta, \sigma$ and $\mathrm{G}$.

Ring width standard deviation $(\bar{\sigma})$ is a measure of dispersion of the tree ring values around the mean, and like mean sensitivity is often interpreted as indicating the influence of climate on radial growth. Bunn et al. (2013) demonstrated that $\bar{\sigma}$ is usually proportional to $\bar{\zeta}$. Like $\zeta$ and $\sigma$, the Gini coefficient $(\mathrm{G})$ is a measure of interannual variability in a ring width time series, very similar to $\zeta$, except that all possible lags are integrated into the function (e.g. Biondi and Qeadan, 2008). Results for the Gini Coefficient are interpretable in the same way as $\zeta$ and $\sigma$.

First order autocorrelation $(\bar{\phi})$ is a measure of the influence of radial growth in the prior year on the radial growth of the current growing season, measured by simple linear regression of the time series on themselves at a lag of one year. 
Intercorrelation $(\bar{r})$ is the mean Pearson product-moment correlation coefficient calculated from simple linear regression of each time series against a master time series produced from all of the other time series at the site.

The expressed population signal (EPS), based on tree-mean time series, measures how well a site-mean time series approximates its hypothetically perfect mean time series, based on an infinite number of trees (e.g. Cook and Kairiukstis, 1990). An EPS value of 0.85 has been suggested as a threshold for acceptable reliability (Wigley et al., 1984). The EPS is only presented for the SW chronology (Fig. 2), though all sites included in this study exceeded the EPS threshold over a large portion of the common time series length.

Direct comparisons of the SW site-mean values and the modern Quercus median sitemean values, and their $2 \sigma$ ranges, are presented for each statistic. In addition, site-mean relationships between modern Quercus ring width time series statistics and water availability were assessed through regression of all site-mean values for each statistic on the corresponding grid cell values $\left(0.5^{\circ} \times 0.5^{\circ}\right)$ for monthly long-term mean estimated soil moisture, 1948-2012 (Fan and van den Dool, 2004; Huang et al., 1996; van den Dool et al., 2003) obtained from the Physical Sciences Division of NOAA/ESRL; http://www.cpc.ncep.noaa.gov/soilmst/leaky_glb.htm). Experimental results suggest "the calculated soil moisture (with $\mathrm{Wmax}=760 \mathrm{~mm}$ ) agrees best with the observed soil moisture in the top 1.3 meters of soil." (Huang et al., 1996). The long-term annual mean monthly estimated soil moisture was chosen for these analyses to allow comparisons with the typical time frame of previous petrified wood and paleoenvironmental analyses.

Results for each statistic are presented textually, as simple linear regressions of the sitemean statistics on the long-term annual mean monthly estimated soil moisture values from the 
grid cell for each site, and as spatial representations of the estimated soil moisture for the continental United States overlain with symbols at the location of each tree site. The textual comparisons indicate the median site-mean value for each time series statistics from the 126 modern Quercus sites, and for two species, Q. alba and Q. douglasii. Q. alba is usually found in mesic environmnents, while $Q$. douglasii grows in the dry valleys of central California, a region characterized by a strongly Mediterranean climate. Inclusion of statistical mean values for these two species indicates species-level differences between Quercus from more mesic and more xeric environments. Many of the spatial representations are presented as Supplementary Material. No corrections were made for site related differences, such as elevation, aspect, substrate, or proximity to flowing water. The correlation coefficients from regressions of the ring width time series on the soil moisture data were realized on the spatial representations by color coding the site symbols after subdividing the distribution of each statistic into three arbitrary divisions. The same divisions and colors were used for the symbols on both the regression and spatial plots. A second y-axis on each regression plot presents the mean and $2 \sigma$ values (where appropriate) for the SW time series. The SW values are indicated on the second y axis, because direct comparison with modern soil moisture is impossible.

\subsubsection{Modified Coexistence Approach}

The standard Coexistence Approach (Mosbrugger and Utescher, 1997; Utescher et al., 2014) involves identifying the nearest living relatives (NLR) for the taxa present at a paleo-site. Multiple taxa are then used to determine a common climate distribution (range), typically mean annual temperature, for the NLRs, with the assumption that the fossil taxa had the same climate requirements as the NLR. In our Modified Coexistence Approach, we include tree ring site-mean 
statistics from the dominant genus at the paleo site as an additional source of information. Regression of modern site-mean tree ring time series statistical values on a local climate parameter, followed by comparison of the modern values with site-mean values from the paleosite for the same time series statistic(s), are interpreted as indicating environmental characteristics for the paleo-site. Such an approach is particularly useful when the dominant genus has a very wide modern distribution that includes many geographically overlapping species (e.g. Quercus- 80+ species in the United States), and when the fossil morphology is inadequate for indicating a single species NLR. Choosing species as potential NLRs is simplified when the number of species considered is reduced based on the environmental characteristics indicated by the tree ring data. The use of tree ring time series from both modern and fossil contexts can be considered a physiognomic approach as described by Utescher et al. (2014).

In this study, we determined the modern geographic distributions of each genus present at the SW locality by combining the geographic distributions for appropriate modern species from each genus, data available as shape files from the United Stated Geological Survey (U. S. Geological Survey, 1999; http://esp.cr.usgs.gov/data/little/). These maps provide the maximum geographic occurrence for each species, but of course do not indicate their presence or proportions in any given area within the distribution boundary. But recognizing that (1) all but one of the nine genera identified at the SW locality are present in the United States, that (2) the genera currently present in the United States do co-occur, and that (3) a dominant genus is present at the SW locality (Quercus), another modern forest character, the "forest type groups" (Ruefenacht et al., 2008; http://data.fs.usda.gov/geodata/rastergateway/forest_type), can also be considered. Twenty eight forest type groups have been recognized by the United States Department of Agriculture, Forest Service (USDA Forest Service) for the conterminous United 
States (i.e. not including Hawaii and Alaska). Of these, three forest type groups are Quercus dominant. The Quercus dominant forest type group Oak/Hickory, as defined by the USDA Forest Service, is the best match as it includes many of the same genera present at the SW site. The Oak/Gum/Cypress and Oak/Pine forest type groups differ in the genera included and/or in the generic dominance.

\section{Results}

As part of this project, a sample from one of the pillow basalts was recovered from the matrix surrounding the SW specimens and sent to the ${ }^{40} \mathrm{Ar} /{ }^{39} \mathrm{Ar}$ Argon Geochronology Laboratory of Oregon State University for analysis (Thermo Scientific ${ }^{\mathrm{TM}}$ Argus VITM multicollector mass spectrometer). An 18-step incremental heating analysis yielded a weighted Plateau Age mean $(13.79 \pm 0.09 \mathrm{Ma})$ that was indistinguishable from the Total Fusion mean age (13.85 $\pm 0.09 \mathrm{Ma}$; Supplementary material).

Analyses in this study identified significant crossmatching between twenty six ring width time series measured on polished slabs of petrified Quercus originating at the SW locality (Appendix 1. Table 1). The total number of trees represented is less than twenty six, because some of the time series represent measurements made on different slabs from the same stem, including: (1) where two radii were measured on a single slab (e.g. SW 2a and SW 2b; JC1a and JC1b), (2) where multiple slabs from the same specimen were available from the person who cut the stem (e.g. ER 1Ha, ER 1Hb; ER 2h, ER 2L), and (3) where measurements were made on multiple slabs purchased by a collector directly from the person who had cut the stem (e.g. WW 01a and WW 01b; WW 04a and WW 04b; WW Wa and WW Wb; SW 1 and SW 2.) Two specimens, ZM 1057 and RM 1272a, also originated from a single stem, but this fact was not recognized until time series statistics and visual inspection were done. The correlation coefficient 
and T-score between ZM 1057 (138 measured rings) and RM 1272a (166 measured rings) was the highest of all the correlation coefficients and all the T-scores from all possible combinations of two time series from amoung the 26 time series $(\mathrm{r}=0.73, \mathrm{~T}=12.5, \mathrm{~N}=138, \mathrm{p}<0.0001)$, a strong indication that the two specimens came from the same stem. Absolute proof of the single stem origin may be impossible, but comparison of RM 1272a and a photograph of specimen ZM 1057 revealed strong similarities in specimen circumference, positions of cracks, color and morphological characteristics preserved from the original xylem. Given that assumption, we may conclude that samples from seventeen different stems were measured for this project. Fig. 2 presents a 252-year mean ring width master time series (or chronology) produced from the twenty six individual time series and an EPS assessment of signal strength from the 17 tree-mean time series.

\subsection{Statistical Comparisons of modern and SW Quercus}

The $\overline{y r}$ for the SW Quercus is 141 years. The median site-mean value for the 126 modern Quercus sites is 187 years. Values for two modern species, Q. alba and Q, douglasii are 201 years and 177 years, respectively (Appendix 1. Table 2)

The $\overline{r w}$ for the SW Quercus is $1.41 \mathrm{~mm}$. The median site-mean value for the 126 modern Quercus sites is $1.01 \mathrm{~mm}$. Values for two modern species, Q. alba and $Q$, douglasii are $1.26 \mathrm{~mm}$ and $0.77 \mathrm{~mm}$, respectively. A regression of all the $\overline{r w}$ values for the modern Quercus on annual mean monthly soil moisture is presented in Fig. 3a, along with $2 \sigma$ values for each site. The SW site-mean and $2 \sigma$ values for the SW trees are included on a second y axis. A second plot places each site on a map of the United States with annual mean monthly estimated soil moisture as the 
background. Three symbols and colors indicate partitioning of the $\overline{r w}$ distribution into three arbitrary divisions (Fig. 3b).

Fig. 3a 90mm (1 column)

Fig. 3b 90mm (1 column)

The $\bar{\zeta}$ for the SW Quercus is 0.20 . The median site-mean value for the 126 modern Quercus sites is 0.26 . Values for two modern species, $Q$. alba and $Q$, douglasii, are 0.22 and 0.37, respectively. A regression of all the $\bar{\zeta}$ values for the modern Quercus on annual mean monthly soil moisture is presented in Fig. 4a, along with $2 \sigma$ values for each site. The SW sitemean and $2 \sigma$ values for the SW trees are included on a second y axis. A second plot places each site on a map of the United States with annual mean monthly estimated soil moisture as the background. Three symbols and colors indicate partitioning of the $\bar{\zeta}$ distribution into three divisions (Fig. 4b).

Fig. 4a 90mm (1 column) 
Fig. 4b 90mm (1 column)

The $\bar{\sigma}$ for the SW Quercus is 0.21 . The median site-mean value for the 126 modern Quercus sites is 0.33 . Values for two modern species, $Q$. alba and $Q$, douglasii are 0.30 and 0.41 , respectively. Regression of all the $\bar{\sigma}$ values for the modern Quercus on annual mean monthly soil moisture is very similar to the results for $\bar{\zeta}$ (Supplementary Fig 1a), another measure of ring width varibility, as is a map of their geographic distributions (Supplementary Fig. 1b).

The $\bar{G}$ for the SW Quercus is 0.12 . The median site-mean value for the 126 modern Quercus sites is 0.18 . Values for two specific modern species, $Q$. alba and $Q$, douglasii are 0.16 and 0.23 , respectively. Regression of all the $\bar{G}$ values for the modern Quercus on annual mean monthly soil moisture is very similar to the other measures of ring width variability, $\bar{\zeta}$ and $\bar{\sigma}$ (Supplementary Fig 2a), as is a map of their geographic distributions (Supplementary Fig. 2b).

The $\bar{\phi}$ for the SW Quercus is 0.16 . The median site-mean value for the 126 modern Quercus sites is 0.36 . Values for two modern species, $Q$. alba and $Q$, douglasii are 0.39 and 0.29 , respectively. A regression of all the $\bar{\phi}$ values for the modern Quercus on annual mean monthly soil moisture is presented in Fig. 5, along with $2 \sigma$ values for each site. The SW sitemean and $2 \sigma$ values for the SW trees are included on a second y axis. A second plot places each site on a map of the United States with annual mean monthly estimated soil moisture as the background, with symbols and colors identical to Fig. 5 (Supplementary Fig. 3).

Fig. 5 90mm (1 column) 
The $\bar{r}$ for the SW Quercus is 0.57 . The median site-mean value for the 126 modern Quercus sites is 0.64 . Values for two specific modern species, Q. alba and $Q$, douglasii are 0.60 and 0.70 , respectively. A regression of all the $\bar{r}$ values for the modern Quercus on annual mean monthly soil moisture is presented in Fig. 6a. The SW site-mean value for the SW trees is included on a second y axis. A second plot places each site on a map of the United States with annual mean monthly estimated soil moisture as the background (Fig. 6b). Three symbols and colors indicate partitioning of the $\bar{r}$ distribution into three divisions.

Fig 6a $90 \mathrm{~mm}$ (1 column)

Fig. 6b 90mm (1 column)

\subsection{Modified Coexistence Approach}

Figure 7 presents the modern geographic distributions for genera present at the SW locality and occurring in modern mesic environments, and high resolution locational information for the Oak-Hickory forest type group. The species included in the generic composites were chosen based on locational evidence from the comparison of highly significant regressions of modern Quercus statistics on estimated soil moisture and the same site mean statistics from the SW locality Quercus (Figs. 3a, 3b, 6a, 6b, Supp. Figs. 1a, 1b, 2a, 2b). Characteristics of the SW locality paleomineralized wood morphology allow sub-genus identification of the Red Oak and White Oaks groups, so the distributions of common Eastern United States members of the Red Oak group $(Q$. coccinea, $Q$. falcata, $Q$. marilandica, $Q$. rubra, $Q$. velutina $)$ and White Oak group 
(Q. alba, Q. bicolor, Q. macrocarpa, Q. prinus, Q. muehlenbergii) are presented separately. Multiple species occurring in the Eastern United States from each of the other genera were merged into generic-level distributions, and then differenced to produce a distribution indicating regions where they can co-occur. This merged genera distribution includes Carya (C. glabra, $C$. ovata, C. tomentosa), Fraxinus (F. americana), Juglans (J. cinerea, J.nigra), Juniperus (J. virginiana), Populus (P. deltoides), and Ulmus (U. americana). The distribution of Picea rubra is presented separately, because it is the only genus present with very limited distribution in the United States.

\section{Discussion}

Statistically significant crossmatching has now been identified among ring width time series from many different petrified trees originating at the same location, specifically among twenty six ring-width time series from seventeen Miocene-aged permineralized Quercus stems (Appendix 1. Table 1). Common changes noted in ring width patterns between multiple trees over many decades in continuous series of ring widths, without long-term trends, releases or suppressions are certainly related to changes in annual climate. Fig. 2 presents a 252 -year mean ring width time series (chronology) produced from 17 tree-mean SW ring width time series.

Petrified wood at the Stinking Water site, described as locality P4007 in Chaney and Axelrod (1959), present as stems within a matrix of ash and pillow basalts up to four meters thick. The stems of the Stinking Water specimens are almost all in vertical position, without significant deformation in the transverse plane, indicating burial in situ. The presence of pillow basalts in the entombing matrix provides evidence for flooding of the forest prior to the encasement, likely requiring a riparian environment with significant topography. $\mathrm{A}{ }^{40} \mathrm{Ar} /{ }^{39} \mathrm{Ar}$ 
weighted Plateau Age mean of $13.79 \pm 0.09$ Ma for the feldspar component of a Stinking Water pillow basalt, determined as part of this study, places the age of the Stinking Water petrified wood within about $1 \mathrm{Ma}$ of the end of the middle Miocene Climate Optimum ( 15-17 Ma).

Potential problems with environmental interpretations of tree rings in petrified wood have previously been recognized, including concerns raised by natural variation (Poole, 2000a), and taxonomy, ontogeny and paleoclimate (Falcon-Lang, 2005a). These potential problems were overcome in this study through (1) the availability of a site with in situ preservation of stems, (2) remarkable preservation of the specimens such that subcellular features can be recognized, (3) clear identification of the tree genus, Quercus, (4) recovery of specimens containing a minimum of 100-200 rings, indicating a mature forest, (5) standardization of the ring width time series, ensuring that biological growth trends do not affect the time series statistics, (6) determination of significant crossmatching between the individual time series, indicating growth that is sensititive to climate changes, and (7) statistical evidence, an Expressed Population Signal (EPS; e.g. Cook and Kairiukstis, 1990), based on comparison with a hypothetically perfect mean time series drawn from an infinite number of samples, that the mean time series between the SW trees reliably approximates the average Quercus growth at the site. The evidence for significant crossmatching between the SW petrified wood specimens (Appendix 1. Table 1) and for strong site-mean signal reliability (Fig. 2), allow heretofore unmatched evidence that the tree ring statistics produced from petrified wood specimens can provide a reliable measure of the common stand-level radial growth patterns.

The genus Quercus is still very common in the United States, and has been sampled extensively for dendrochronological analysis. Comparisons of site-mean ring width time series statistics and climate relationships amoung modern Quercus may indicate environment/tree 
growth relationships that can be extrapolated to the time when the SW specimens were alive.

Regressions of site-mean statistics from the 126 modern Quercus sites on estimated soil moisture for the 126 grid cells containing the sites are provided as indications of the strength of the statistical relationships between ring width time series statistics from modern Quercus and their growing environment. No corrections were made for site elevation, aspect, substrate, proximity to water, etc. Also calculated were species specific statistics for two Quercus species, Q. alba and $Q$. douglasii, that tend to be found in more mesic sites and more xeric sites, respectively (Appendix 1. Table 2). Q. alba is found in a fairly continuous distribution starting in the central United States, states bordering the west side of the Mississippi River, east to the Atlantic Ocean, especially between about $33^{\circ} \mathrm{N}$ and $43^{\circ} \mathrm{N}$. Q. douglasii grows in California, on the coastal ranges, the inner valleys and in the foothills of the Sierra Nevada; a region characterized by wet winters and very dry summers.

\subsection{Statistical Comparisons of modern and SW Quercus}

Site-mean statistical measures of Quercus ring width time series presented in this study reveal different aspects of Quercus tree growth for each site, including average radial growth, interannual growth variability, the importance of prior radial growth to current radial growth, and the strength of the common growth variability. All regressions of the site-means of the 126 modern Quercus ring width time series statistics on mean annual soil moisture show statistically significant relationships amoung all the sites (Figs. 3a, 4a, 5, and 6a; Supplementary Figures 1a, 2a), though the relationship between soil moisture and mean ring width (Fig. 3a) is only minimally significant and isn't a linear relationship. The $2 \sigma$ ranges for each statistic (except $\bar{r}$, where crossdating is required) are presented for each site to indicate the importance for each 
statistic of adequate sample depth when making environmental inferences from individual ring width time series statistics.

A median site-mean tree age estimate for the modern time series based on the time series with the most rings from each tree at each site (modern Quercus median $\overline{y r}=187$ years), exceeds the mean tree age based on the SW specimens (SW $\overline{y r}=141$; Table 2), but the potential sources of ring loss for the SW specimens suggest the actual mean age at death for the SW specimens was much older. Many factors can reduce the number of rings available for observation and measurement on the SW specimens, including (1) the loss of wood on the outside of each specimen during preservation, likely 10-40 years of sapwood (the portion of the wood where sap/water is still flowing during the growing season), (2) rings not available because of the height of the specimen above "breast height", the accepted sampling height for ring widths in living trees (Fritts, 1976), (3) occasional unmeasureable rings caused by post-deposition deformation near the center (pith) and (4) radial cuts made by the owner to produce a saleable product (e.g. bookends). Yet even with these caveats, the minimum estimated tree ages for the SW specimens indicate a mature forest.

Site-mean ring width $(\overline{r w})$ for the SW trees $(\mathrm{SW} \overline{r w}=1.41 \mathrm{~mm})$ exceeds the median value for the 126 modern Quercus ring width site means (modern Quercus median = $1.01 \mathrm{~mm}$; Appendix 1. Table 2). The median site-mean ring width value for modern Quercus alba sites (N $=48$ ), a species that tends to grow in mesic environments, is much closer to the SW mean than the collective value (modern $Q$. alba median $\overline{r w}=1.27 \mathrm{~mm}$; Appendix 1. Table 2.) Regression of the site-mean ring widths on the annual mean estimated soil moisture yields a correlation coefficient that is significant, but which explains only $9 \%$ of the variance in a simple linear regression $(r=0.30, N=126, p<0.0001$; Fig. 3a). So the relationship between mean ring width 
and soil moisture cannot be used as a reliable indicator of the moisture status at the modern sites. A map of annual monthly mean mean soil moisture overlain with symbols that divide the 126 site mean values into three parts confirms that sites with mean ring widths over $1.0 \mathrm{~mm}$ only occur in mesic regions (Fig. 3b). The SW $\overline{r w}$ exceeds the $\overline{r w}$ for $Q$. alba, a Quercus species that tends to grow in sub-mesic to mesic environments, indicating a mesic environment when the SW trees were growing. Yet large mean ring widths are not consistent with some estimates of ${ }_{\mathrm{p}} \mathrm{CO}_{2}$ below the modern pre-industrial value of $270 \mathrm{ppm}$ for the middle Miocene, as suggested by some research based on alkenones (Pagani et al., 1999) and Boron isotopes (Pearson and Palmer, 2000). This issue is discussed in more detail below.

The $\bar{\zeta}$ value at the $S W$ locality $(S W \bar{\zeta}=0.20)$ is lower than the median $\bar{\zeta}$ value for the 126 modern Quercus sites (modern Quercus median $\bar{\zeta}=0.26$; Fig. 4a and Appendix 1. Table 2) and slightly lower than the median $\bar{\zeta}$ value for modern Quercus alba $=0.22 ; \mathrm{N}=48$; Appendix 1 Table 2), a species that tends to grow in sub-mesic to mesic environments. The median $\bar{\zeta}$ value for $Q$. douglasii sites, a species native to the Mediterranean climate of California, is much higher (median $\bar{\zeta}=0.37 ; \mathrm{N}=29$; Appendix 1. Table 2), indicating greater sensitivity to climate than $Q$. alba. Regression of 126 modern Quercus $\bar{\zeta}$ on annual mean monthly estimated soil moisture reveals a highly significant linear relationship (Fig. 4a). Note that there are no values below $\sim \bar{\zeta}=0.22$ when the annual estimated mean soil moisture is below $400 \mathrm{~mm}$ (Fig. 4a), a $\bar{\zeta}$ value exceeding the $\mathrm{SW} \bar{\zeta}$ value of 0.20 . A map of annual monthly mean soil moisture overlain with color coded symbols for the site locations shows a clear spatial division beween the site-mean $\bar{\zeta}$ extremes, a division that coincides with more 
mesic and less mesic environments (Fig. 4b). The SW $\bar{\zeta}$ value is consistent with growth in a mesic environment.

The variability of ring width values at the SW locality as measured by the ring width standard deviation $(\bar{\sigma})$ is less than the median for the 126 modern site means $(S W \bar{\sigma}=0.22$; median $\bar{\sigma}=0.30$; Appendix 1. Table 2), consistent with the result using $\zeta$ and interpretable in the same way. The SW $\bar{\sigma}$ value is also lower than the median $\bar{\sigma}$ value for modern Quercus alba sites median $\bar{\sigma}=0.30 ; \mathrm{N}=48 ;$ Appendix 1 . Table 2) and much lower that the median $\bar{\sigma}$ value for $Q$. douglasii median $\bar{\sigma}=0.41 ; \mathrm{N}=29$; Appendix 1 . Table 2). As noted for $\bar{\zeta}$, the lowest $\bar{\sigma}$ values occur only when the annual estimated mean soil moisture is above $400 \mathrm{~mm}$ (Supplementary Fig. 1a). The placement of $\bar{\sigma}$ values on a map of annual monthly mean soil moisture, as in Figs. $3 \mathrm{~b}$ and 4 b, shows very similar spatial distribution to the $\bar{\zeta}$ results (Supplementary Fig. 2b). The SW $\bar{\sigma}$ value is consistent with modern Quercus growing in a mesic environment.

The Gini coefficient $(G)$, like $\bar{\zeta}$ and $\bar{\sigma}$, is a measure of the variability in the ring width time series, except that all possible temporal lags are integrated into the function (e.g. Biondi and Qeadan, 2008). The Gini coefficient for the SW specimens $(\bar{G}=0.12)$ is lower than the median value of the 126 modern site-mean $\bar{G}$ (median $\bar{G}=0.18$ ). The pattern of correlations from regression of the annual mean estimated soil moisture on the modern Quercus site-mean $\bar{G}$ (Supplemental Fig. 2a) is almost identical to the patterns in Fig. 3a and in Supplemental Fig. 1a. As with $\bar{\sigma}$, a plot of $\bar{G}$ values on a map of monthly mean soil moisture shows clear spatial separation of the $\bar{G}$ extremes (Supplementary Fig. 2b). The SW $\bar{G}$ value is consistent with modern Quercus growing in a mesic environment. 
Correlation coefficients from regressions on the three measures of site-mean ring width variability, mean sensitivity $(\bar{\zeta})$, standard deviation $(\bar{\sigma})$ and the Gini cofficient $(\bar{G})$, are all highly significant (Fig. 3a, and Supplementary Figs. 1a and 2a), with almost identical results that explain more than $55 \%$ of the annual mean monthly estimated soil moisture variance $(\bar{\zeta}, \mathrm{r}=$ $0.79 ; \bar{\sigma}, \mathrm{r}=0.74$; and $\bar{G}, \mathrm{r}=0.75$ ). So, while there seem to be legitimate theoretical grounds for replacing mean sensitivity with different statistics (Bunn et al., 2013; Biondi and Qaeadan, 2008; Strackee and Jansma, 1992), the similarity between the regression results using mean sensitivity and the recommended substitute statistics, standard deviation (Bunn et al., 2013; Strackee and Jansma, 1992) and the Gini cofficient (Biondi and Qeadan, 2008), suggest that mean sensitivity is adequate for basic assessments of Quercus ring width climate sensitivity. In fact, the $\bar{\zeta} 2 \sigma$ range for Quercus is narrower than for $\bar{\sigma}$ and $\bar{G}$ (Fig. 3a, and Supplementary Figs. 1a and 2a), suggesting fewer specimens may be required to obtain an accurate estimate of $\bar{\zeta}$ in Quercus, assuming there is adequate time series length. The importance of time series length cannot be overemphasized. To that end, the individual SW Quercus ring width time series were used to calculate a 10-year running $\zeta$ (Supplementary Fig. 4). The 10-year running $\zeta$ values for the time series often fall far outside the $2 \sigma$ values for the overall time series average (Supplementary Fig. 4), indicating the unreliability of interpreting environmental characteristics from mean sensitivity and similar time series statistics when segment lengths are short or when only a few long time series are available.

The $\bar{\phi}$ of the SW time series (SW $\bar{\phi}=0.32$ ) is less than the median $\bar{\phi}$ value for the modern Quercus sites median ( $\bar{\phi}=0.46$; Fig. 5 and Appendix 1. Table 2), though the SW $\bar{\phi}$ value exceeds the $\bar{\phi}$ at 21 of 126 modern sites. In the modern Quercus datasets analyzed, the 
higher $\bar{\phi}$ values $(\bar{\phi} \geq 0.50)$, never occur when annual mean estimated soil moisture is less than 400 mm and geographically only occur in the Eastern United States (Supplementary Fig. 3).

This relationship indicates that modern Quercus sites with $\bar{\phi}$ exceeding 0.50 are likely to occur in mesic environments. The $\bar{\phi}$ for the SW specimens does not exceed this threshold, but values between $\bar{\phi}=0.30-0.50$, bracketing the SW $\bar{\phi}$ value, occur across all values for estimated soil moisture, so the SW site-mean $\bar{\phi}$ value is not inconsistent with a mesic growing environment and may indicate microsite influences, or perhaps differences in the annual growth trajectory between the modern and mid-Miocene Quercus. Autocorrelation $(\phi)$ of ring widths is usually related to environmental conditions in previous years that affect bud formation, storage of photoassimilates, root and fruit formation, and in leaf retention if the trees are non-deciduous trees (Fritts, 1976). In Quercus, the dominant cause of autocorrelation in the ring width time series is the early growing season requirement for the use of stored photoassimilates. All Quercus, in fact all "ring porous" angiosperms, require stored photoassimilates early in the growing season to produce the large vessels required to transport water and sap at a time when no leaves are present to photosynthesize (e.g. Barbaroux and Breda, 2002; Barbaroux et al., 2003), a process that has also been identified using time series of stable carbon isotopes (Hill et al., 1995; Kagawa et al., 2006; Monserud and Marshall, 2001). The evidence for strong autocorrelation in ring width time series requires dependence on stored photoassimilates for a large proportion of the growth in each annual increment. The low value $\bar{\phi}$ value for the SW specimens may indicate that a lower proportion of the annual growth was based on stored photoassimilates than in most modern mesic-site Quercus. A reduction in this proportion could 
be caused by a more rapid shift from growth based on stored photoassimilates to growth based primarily on current photosynthesis.

Regression of the modern Quercus site-mean $\bar{r}$ values on annual mean monthly estimated soil moisture is highly significant, indicating the importance of water availability, and therefore of climate, to Quercus radial growth. Values of $\bar{r}<0.6$ occur only where the annual mean monthly estimated soil moisture exceeds $300 \mathrm{~mm}$ (Fig. 6a). Values for $\bar{r}$ exceeding 0.6 can occur at some mesic sites (Fig. 6a), likely indicating the microsite conditions of locations typically chosen to emphasize climate relationships during dendrochronological sampling (e.g. ridgelines, rocky substrates). Yet the extremes of the $\bar{r}$ distribution are almost perfectly discrete, geographically (Fig. 6b), indicating that sites where higher $\bar{r}$ values coincide with higher annual mean monthly estimated soil moisture occur mostly along the margins between the extremes. The SW site-mean time series average intercorrelation value $(\bar{r}=0.57)$ is lower than the median of the modern site-mean intercorrelations (median $\bar{r}=0.64$; Appendix 1. Table 2), is slightly lower than the median $\vec{r}$ value for modern Quercus alba sites (median $\bar{r}=0.61 ; \mathrm{N}=$ 48; Appendix 1. Table 2), and falls within the range of modern Quercus values that only occur in mesic environments.

Regressions of site-mean time series statistics from 126 modern Quercus sites on annual $0.5^{\circ} \times 0.5^{\circ}$ gridded soil moisture (CPC) reveal highly significant relationships for many time series statistics, including site-mean ring widths $(\overline{r w})$, three site-mean measures of ring width variability: mean sensitivity $(\bar{\zeta})$, standard deviation $(\bar{\sigma})$ and the Gini coefficient $(\bar{G})$, and sitemean intercorrelation ( $\bar{r}$ ) (Figs. 3a, 4a, and 6a; Supplementary Figs. 1a and 2a). With the exception of site-mean first order autocorrelation $(\bar{\phi})$, where the interpretation is equivocal, 
placement of the SW site-mean values on the modern regression plots indicates a mesic growing environment for the SW Quercus.

\subsection{Modified Coexistence Approach}

The genera represented in the permineralized wood at the SW locality are identifiable based on xylem morphology, and most are known to coexist in modern settings, presenting an ideal scenario for a modified Coexistence Approach (Mosbrugger and Utescher, 1997; Utescher et al., 2014). In a classic Coexistence Approach, a nearest living relative is identified for each of the coexisting taxa from the paleolocation based on morphological comparisons with modern taxa. Mean annual temperature ranges for each of the modern taxa are then compared to determine a temperature range common to all the taxa. This temperature range is interpreted as an indication of the environmental conditions present when the plants at the paleosite were growing. In our modified Coexistence Approach, the first requirement is dendrochronologically crossmatched petrified wood from many trees with a modern taxon equivalent. Then modern site-mean ring width time series statistics, data from many sites using the same taxon, are regressed on a local climate parameter (e.g. estimated soil moisture). Then the site mean ring width statistical values from the paleo-specimens are compared to the modern values, noting the value of the climate parameter and the geographic positioning of sites with similar values. Next, a common region of occurrence for all the pertinent taxa is identified based on the geographic distributions of the taxa. If many species are present in some of the genera, then the geographic positioning indicated by the ring width time series statistics can be used to reduce the number of species included. The overlap regions of the generic geographic distributions are then used to indicate the modern region with the most similarity to the paleo-site. 
In the specific example presented in this study, the NLR for each taxon can clearly be identified to the genus level. The additional information required to attempt identification to the species level would have required loan and modification of museum/collector specimens, so analyses were done to the level of genus. Quercus is the dominant genus at the SW site, and was used for the dendrochronological crossmatching presented in Figure 2. Comparison of the site mean ring width statistical values from the paleo-specimens with the estimated available moisture (Fig. 3a and 6a; Supplementary Figs. 1a and 2a) and the locations of modern Quercus sites with similar statistical values (Fig. 3b and 6b; Supplementary Figs. 1b and 2b) indicates a mesic growing environment such as is found in the central Eastern United States. Other angiosperm genera present at the SW locality were Carya, Ulmus, Fraxinus, Juglans and Populus, with the conifers Juniperus, Picea and Metasequoia also in evidence. This combination of genera, with the exceptions of the Picea and Metasequoia, suggests an oak-dominated temperate broadleaf forest similar to the modern Oak-Hickory forest type group found in the highlands of the East Central United States (Fig. 7). Most modern Oak-Hickory forests are considered climatically humid, though they grade to sub-humid along the fringes of the central plains (Burns, 1983). Ulmus, Fraxinus and Populus, often co-occur in riparian environments across the modern highlands of the East-Central United States where they are sometimes found in proportions high enough to form the Elm-Ash-Cottonwood forest type. Metasequoia is no longer present in North America, but Juniperus is broadly distributed across the same modern highlands of the East Central United States. Picea is not typically found south of about $43^{\circ} \mathrm{N}$ in modern times, except for the higher elevations of the Appalachian Mountains of the Southeastern United States, where Picea rubens (i.e. Picea rubra) occurs as far equatorward as about $35^{\circ} \mathrm{N}$ in eastern Tennessee and western North Carolina at elevations above about 1,350 meters. Picea 
rubens requires a cool, moist oceanic climate, with annual precipitation between $875 \mathrm{~mm}$ and $2,000 \mathrm{~mm}$.

Given the SW generic and modern forest type group associations presented in Figure 7, the closest modern environmental equivalent seems to be in the Eastern Temperate Forests, especially the central and southern Appalachian Mountains and the Ozark/Ouachita Mountain Highlands, indicated by the ovals on Figure 7. Site-mean time series statistical values for modern Quercus sites from those regions are very similar to those calculated for the Stinking Water Quercus (Figs. 3a, 6a, Supp. Fig. 1a, 2a), supporting this interpretation. Values for $\bar{\zeta}, \bar{\sigma}, \bar{G}$ and $\bar{r}$ similar to those calculated for the SW Quercus, are often located along the spine of the central and southern Appalachian Mountains and in the Ozark/Ouachita Mountain Highlands (Fig. $3 b$ and 6b; Supplementary Figs. $1 b$ and 2b). Absence of Picea in the Ozark/Ouchita Mountain Highlands is likely caused by lower maximum elevations and geographic isolation of those areas, so we do not exclude that region from consideration as the closest modern analog. Thus, the geographic ranges for modern co-occurrence of most of the genera recovered from the SW locality and the environments indicated by the position of the SW site-means relative to the modern Quercus distributions are consistent with a warm temperate evergreen broadleaf and mixed forest transitioning to a temperate deciduous broadleaf forest at about 13.8 Ma (Pound, 2008).

Fig. 7 190mm (full width)

Comparisons of modern and SW Quercus ring-width related statistics, and their relation to annual monthly mean estimated soil moisture, indicate a warm mesic climate when the SW 
locality trees were growing. Modern co-occurrence of genera present at the SW locality, similarity to the Oak-Hickory forest type group and Quercus locations in the United States where modern and SW time series statistics are the most similar, indicate an environment similar to the modern central and southern Appalachian Mountains of the Eastern United States or the Ozark/Ouachita Mountains further inland (Fig. 7). The Mean Annual Temperature (MAT) ranges over the central and southern Appalachian Mountains are $\cong 7^{\circ} \mathrm{C}$ to $\cong 12^{\circ} \mathrm{C}$ and $\cong 10^{\circ} \mathrm{C}$ to $\cong 15$ ${ }^{\circ} \mathrm{C}$, respectively. The Mean Total Annual Precipitation (MAP) ranges over the same regions are $\cong 750 \mathrm{~mm}$ to $\cong 1260 \mathrm{~mm}$ and $\cong 1000 \mathrm{~mm}$ to $\cong 1800 \mathrm{~mm}$, respectively. These values for MAT and MAP do not account for changes in elevation, an important factor in a mountainous region, and the presence of Ulmus, Fraxinus and Populus indicates a riparian environment, therefore lower elevations, so the best estimates are the middle to upper ends of the stated ranges for the MAT, $\cong 10{ }^{\circ} \mathrm{C}$ to $\cong 15{ }^{\circ} \mathrm{C}$, and the middle to lower ends of the ranges for the MAP, $\cong 750 \mathrm{~mm}$ to $\cong 1200 \mathrm{~mm}$.

The hydrometeorology of modern eastern Oregon is semi-arid, a product of the strong rain shadow east of the Cascade Range of western Oregon. Yet the environment of eastern Oregon was very different during the middle Miocene. Paleobotanical data indicate the southern Cascade Range of the middle Miocene was 700-900 m lower than today (Kohn et al., 2002; Kohn and Fremd, 2007), with orogenesis resuming during the late Miocene (Reiners, 2002; Kohn et al., 2002; Kohn and Fremd, 2007; Mustoe and Leopold, 2014). The lower elevations of the Cascade Range during the middle Miocene allowed air parcels to proceed eastward almost unhindered from the Pacific Ocean.

\subsection{Conclusions}


The interpretation of environmental and growth conditions for the SW locality at $\sim 13.8$ Ma is consistent with recent paleoenvironmental information for the middle Miocene Climate Transition (MMCT). The ${ }^{40} \mathrm{Ar} /{ }^{39} \mathrm{Ar}$ date of $13.79 \pm 0.09$ Ma for the $\mathrm{SW}$ exposure places the SW Quercus entombment immediately after the Middle Miocene Climate Optimum (MMCO) and immediately prior to the largest reduction in oceanic $\delta^{18} \mathrm{O}$ during the MMCT (Holbourn et al., 2013). A recent review of paleobotanical studies suggests that the dominant forest type during the Langhian Stage $(15.97 \pm 0.05$ to $13.65 \pm 0.005 \mathrm{Ma})$ in what is now the northwestern United States was warm temperate evergreen broadleaf and mixed forest transitioning to a temperate deciduous broadleaf forest in the Seravallian Stage (13.65 \pm 0.05 to $11.61 \pm 0.05 \mathrm{Ma}$; Pound, 2012). Early assessments of atmospheric ${ }_{\mathrm{p}} \mathrm{CO}_{2}$ during the $\mathrm{MMCO}(\cong 15-17 \mathrm{Ma})$ and the MMCT

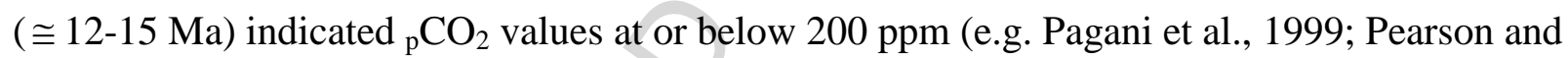
Palmer, 2000), levels seemingly inconsistent with the thriving plantlife present during the midCenozoic (Cowling, 1999), but recent assessments indicate ${ }_{\mathrm{p}} \mathrm{CO}_{2} \cong 260-310 \mathrm{ppm}$ at about 13.8 Ma (e.g. Badger et al., 2013; Foster et al., 2012; Kuerschner et al., 2008; Zhang et al., 2013), in the range of the modern pre-industrial value of ${ }_{\mathrm{p}} \mathrm{CO}_{2} \cong 270 \mathrm{ppm}$. Estimates for ${ }_{\mathrm{p}} \mathrm{CO}_{2}$ at or above 260 ppm during the middle Miocene are more consistent with the results from this study; vigorous growth indicated by the comparison of the SW Quercus $\overline{r w}$ relative to modern Quercus $\overline{r w}$ (Table 2), and by the environmental conditions present at geographic locations indicated by modern coexistence of the paleo-taxa present at the SW site, locations consistent with the comparison of the modern and SW $\overline{r w}$ (Figs. 3a and 3b), $\bar{\zeta}$ (Figs. 4a and 4b), $\bar{\sigma}$ (Supplementary Figs. 1a and 1b), $\bar{G}$ (Supplementary Figs. 2a and 2b), and $\bar{r}$ (Figs. 6a and 6b). Results from the Modified Coexistence Approach, combining interpretations of paleo-site-mean tree ring statistics based on modern site-mean tree ring/climate statistical comparisons with 
evidence from a standard Coexistence Approach, further focuses the modern geographic analogue to the temperate mesic environment of the modern central and southern Appalachian Mountains of the Eastern United States.

\section{Acknowledgements}

We are extremely grateful for the sample access and information provided by the following individuals and organizations: The Herb Zuhl Museum, Las Cruces, NM; The Rice Northwest Museum of Rocks and Minerals; Herb Zuhl; W. Walton Wright; Ed Rigal, Applegate Lapidary; Steve Wolfe, Tom Wolfe Minerals; Steve Speer; Sticks-in-Stones; Dennis Murphy; Geoff Caplette and Nancy McMillan, Head of the Department of Geology, NMSU. We are also grateful to the contributors to and maintainers of the International Tree-Ring Data Bank (ITRDB, http://www.ncdc.noaa.gov/paleo/treering.html) for the modern Quercus ring width data, and to the Physical Sciences Division of NOAA/ESRL for the gridded soil moisture dataset used in this analysis (PSD, http://www.cpc.ncep.noaa.gov/soilmst/leaky_glb.htm). Finally, our thanks to Peter Brewer and Erica Bigio for help with GIS-related issues.

\section{References}

Allen, J.E., 1984. Rock-hard wood dots landscape, The Oregonian, Portland, p. B12. Ammons, R., Fritz, W.J., Ammons, R.B., Ammons, A., 1987. Cross-identification of ring signatures in Eocene trees (Sequoia magnifica) from the specimen ridge locality of the Yellowstone fossil forests. Palaeogeography, Palaeoclimatology, Palaeoecology 60, 97108. 
Badger, M.P.S., Lear, C.H., Pancost, R.D., Foster, G.L., Bailey, T.R., Leng, M.J., Abels, H.A., 2013. CO2 drawdown following the middle Miocene expansion of the Antarctic Ice Sheet. Paleoceanography 28.

Barbaroux, C., Breda, N., 2002. Contrasting distribution and seasonal dynamics of carbohydrate reserves in stem wood of adult ring-porous sessile oak and diffuse-porous beech trees. Tree Physiology 22, 1201-1210.

Barbaroux, C., Breda, N., Dufrene, E., 2003. Distribution of above-ground and below-ground carbohydrate reserves in adult trees of two contrasting broad-leaved species (Quercus petraea and Fagus sylvatica). New Phytologist 157, 605-615.

Biondi, F., Qeadan, F., 2008. Inequality in paleorecords. Ecology 89, 1056-1067.

Brea, M., Artabe, A.E., Franzese, J.R., Zucol, A.F., Spalletti, L.A., Morel, E.M., Veiga, G.D., Ganuza, D.G., 2015. Reconstruction of a fossil forest reveals details of the palaeoecology, palaeoenvironments and climatic conditions in the late Oligocene of South America. Palaeogeography Palaeoclimatology Palaeoecology 418, 19-42.

Brison, A.-L., Philippe, M., Thevenard, F., 2001. Are Mesozoic wood growth rings climateinduced? Paleobiology 27, 531-538.

Bunn, A.G., Jansma, E., Korpela, M., Westfall, R.D., Baldwin, J., 2013. Using simulations and data to evaluate mean sensitivity (zeta) as a useful statistic in dendrochronology. Dendrochronologia 31, 250-254.

Burns, R.M., Tech. Comp., 1983. Silvicultural systems for the major forest types of the United States, in: . (Ed.), Agriculture Handbook 445. U.S. Department of Agriculture, Washington, D.C. 
Camp, V.E., 2013. Origin of Columbia River Basalt: Passive rise of shallow mantle, or active upwelling of a deep-mantle plume?, in: Reidel, S.P., Camp, V.E., Ross, M.E., Wolff, J.A., Martin, B.S., Tolan, T.L., Well, R.E. (Eds.), The Columbia River Flood Basalt Province: Geol Soc Am Special Paper 497. Geological Society of America pp. 181-199.

Camp, V.E., Ross, M.E., Duncan, R.A., Jarboe, N.A., Coe, R.S., Hanan, B.B., Johnson, J.A., 2013. The Steens Basalt: Earliest lavas of the Columbia River Basalts Group, in: Reidel, S.P., Camp, V.E., Ross, M.E., Wolff, J.A., Martin, B.S., Tolan, T.L., Wells, R.E. (Eds.), The Columbia River Flood Basalt Province: Geological Society of America Special Paper 497, pp. 87-116.

Chaloner, W.G., Creber, G.T., 1990. Do fossil plants give a climatic signal? Journal of the Geological Society, London 147, 343-350.

Chaney, R.W., Axelrod, D.I., 1959. Miocene floras of the Columbia Plateau, in: Institute, C. (Ed.). Washington Publishing.

Cook, E.R., Peters, K., 1981. The Smoothing Spline: A new approach to standardizing forest interior tree-ring width series for dendro climatic studies. Tree-Ring Bulletin 41, 45-53.

Cook, E.R., Kairiukstis, L., 1990. Methods of Dendrochronology: Applications in the Environmental Sciences. Springer, New York.

Cowling, S.A., 1999. Perspectives: Paleoecology - Plants and temperature-CO2 uncoupling. Science 285, 1500-1501.

Creber, G.T., 1977. Tree Rings - Natural Data-Storage System. Biological Reviews of the Cambridge Philosophical Society 52, 349-\&. 
Creber, G.T., Chaloner, W.G., 1985. Tree growth in the Mesozoic and the early Tertiary and the reconstruction of paleoclimates. Palaeogeography, Palaeoclimatology, Palaeoecology 52, $35-60$.

Creber, G.T., Chaloner, W.G., 1987. The contribution of growth ring studies to the reconstruction of past climates, in: Ward, R.G.W. (Ed.), Applications of tree-ring studies. BAR International Series 333, B.A.R. publications, Oxford, pp. 37-67.

Creber, G.T., Francis, J.E., 1999. Fossil tree-ring analysis: paleodendrology, in: Jones, T.P., Rowe, N.P. (Eds.), Fossil plants and spores: modern techniques. Geological Society, London, pp. 244-250.

Davies-Vollum, K.S., Boucher, L.D., Hudson, P., Proskurowski, A.Y., 2011. A late Cretaceous coniferous woodland from the San Juan Basin, New Mexico. Palaios 26, 89-98.

Douglass, A.E., 1920. Evidence of climate effects in the annual rings of trees. Ecology 1, 24-32.

Douglass, A.E., 1936. Climatic cycles and tree-growth: A study of cycles. Carnegie Institution of Washington, Washington, DC.

Esau, K., 1960. Anatomy of seed plants. John Wiley and Sons, Inc., New York.

Falcon-Lang, H.J., 2005a. Global climate analysis of growth rings in woods, and its implications for deep-time paleoclimate studies. Paleobiology 31, 434-444.

Falcon-Lang, H.J., 2005b. Intra-tree variability in wood anatomy and its implications for fossil wood systematics and palaeoclimatic studies. Palaeontology 48, 171-183.

Falcon-Lang, H.J., MacRae, R.A., Csank, A.Z., 2004. Palaeoecology of late cretaceous polar vegetation preserved in the Hansen point volcanics, NW Ellesmere Island, Canada. Palaeogeography Palaeoclimatology Palaeoecology 212, 45-64. 
Fan, Y., van den Dool, H., 2004. Climate Prediction Center global monthly soil moisture data set at 0.5 degree resolution for 1948 to present. Journal of Geophysical Research 109.

Foster, G.L., Lear, C.H., Rae, J.W.B., 2012. The evolution of pCO(2), ice volume and climate during the middle Miocene. Earth and Planetary Science Letters 341, 243-254.

Francis, J.E., Poole, I., 2002. Cretaceous and early Tertiary climates of Antarctica: evidence from fossil wood. Palaeogeography Palaeoclimatology Palaeoecology 182, 47-64.

Fritts, H.C., 1976. Tree rings and climate. Academic Press, London.

Fritts, H.C., Swetnam, T.W., 1989. Dendroecology: A tool for evaluating variations in past and present forest environments, in: Begon, M., Fitter, A.H., Ford, E.D., Macfadyen, A. (Eds.), Advances in Ecological Research. Academic Press, Ltd, London, pp. 111-188.

Fritts, H.C., Smith, D.G., Cardis, J.W., Budelsky, C.A., 1965. Tree-Ring Characteristics Along a Vegetation Gradient in Northern Arizona. Ecology 46, 393-401.

Gail, R.W., 1967. Fabulous Stinkingwater-Oregon's Treasureland. Lapidary Journal 21.

Greene, R.C., Walker, G.W., Corcoran, R.E., 1972. Geologic map of the Burns quadrangle, Oregon. U. S. Geological Survey, pp. Map I-680.

Gregory, K.M., 1992. Late Eocene paleoaltitude, paleoclimate and paleogeography of the Front Range region, Colorado. PhD thesis, Department of Geosciences, University of Arizona, Tucson, p. 246.

Hill, S.A., Waterhouse, J.S., Field, E.M., Switsur, V.R., Aprees, T., 1995. Rapid Recycling of Triose Phosphates in Oak Stem Tissue. Plant Cell and Environment 18, 931-936.

Hoadley, R.B., 1990. Identifying Wood: Accurate results with simple tools. The Taunton Press, Newtown, CT. 
Holbourn, A., Kuhnt, W., Clemens, S., Prell, W., Andersen, N., 2013. Middle to late Miocene stepwise climate cooling: Evidence from a high-resolution deep water isotope curve spanning 8 million years. Paleoceanography 28, 688-699.

Holmes, R.L., 1983. Computer-assisted quality control in tree-ring dating and measurement. Tree-Ring Bulletin 43, 69-78.

Huang, J., van den Dool, H., Georgakakos, K.P., 1996. Analysis of model-calculated soil moisture over the United States (1931-93) and application to long-range temperature forecasts. Journal of Climate 9, 1350-1262.

Jefferson, T.H., 1982. Fossil Forests from the Lower Cretaceous of Alexander Island, Antarctica. Palaeontology 25, 681-708.

Kagawa, A., Sugimoto, A., Maximov, T.C., 2006. Seasonal course of translocation, storage and remobilization of ${ }^{13} \mathrm{C}$ pulse-labeled photoassimilate in naturally growing Larix gmelinii saplings. New Phytologist.

Kohn, M.J., Fremd, T.J., 2007. Tectonic controls on isotope compositions and species diversification, John Day Basin, central Oregon. Paleobios 27, 48-61.

Kohn, M.J., Miselis, J.L., Fremd, T.J., 2002. Oxygen isotope evidence for progressive uplift of the Cascade Range, Oregon. Earth and Planetary Science Letters 204, 151-165.

Kuerschner, W.M., Kvacek, Z., Dilcher, D.L., 2008. The impact of Miocene atmospheric carbon dioxide fluctuations on climate and the evolution of terrestrial ecosystems. Proceedings of the National Academy of Sciences of the United States of America 105, 449-453.

Kumugai, H., Fukao, Y., 1992. Resolving volcanic activity of 20MA ago with relative accuracy of 1 YR from tree rings of petrified woods. Geophysical Research Letters 19, 1859-1862. 
LeBlanc, D.C., Terrell, M.A., 2011. Comparison of growth-climate relationships between northern red oak and white oak across eastern North America. Canadian Journal of Forest Research-Revue Canadienne De Recherche Forestiere 41, 1936-1947.

Monserud, R.A., Marshall, J.D., 2001. Time-series analysis of delta C-13 from tree rings. I. Time trends and autocorrelation. Tree Physiology 21, 1087-1102.

Morgans, H.S., 1999. Lower and Middle Jurassic woods of the Cleveland Basin (North Yorkshire), England. Palaeontology 42, 303-328.

Mosbrugger, V., Utescher, T., 1997. The coexistence approach - a method for quantitative reconstructions of Tertiary terrestrial palaeoclimate data using plant fossils. Palaeogeography Palaeoclimatology Palaeoecology 134, 61-86.

Mosteller, F., Tukey, J.W., 1977. Data Analysis and Regression. Addison-Wesley, Reading, Massachusetts.

Mustoe, G.E., Leopold, E.B., 2014. Paleobotanical evidence for the post-Miocene uplift of the Cascade Range. Canadian Journal of Earth Sciences 51, 809-824.

Pagani, M., Freeman, K.H., Arthur, M.A., 1999. Late Miocene atmospheric CO2 concentrations and the expansion of C-4 grasses. Science 285, 876-879.

Pearson, P.N., Palmer, M.R., 2000. Atmospheric carbon dioxide concentrations over the past 60 million years. Nature 406, 695-699.

Poole, I., 2000a. Fossil angiosperm wood: its role in the reconstruction of biodiversity and palaeoenvironment. Botanical Journal of the Linnean Society 134, 361-381.

Poole, I., 2000b. Variation: Nature's spanner or an unrecognized tool? Palaios 15, 371-372. 
Poole, I., van Bergen, P.F., Kool, J., Schouten, S., Cantrill, D.J., 2004. Molecular isotopic heterogeneity of fossil organic matter: implications for delta(13) C-biomass and delta(13) C-palaeoatmosphere proxies. Organic Geochemistry 35, 1261-1274.

Pound, M.J., Haywood, A.M., Salzmann, U., Riding, J.B., 2012. Global vegetation dynamics and latitudinal temperature gradients during the Mid to Late Miocene (15.97-5.33 Ma). EarthScience Reviews 112, 1-22.

Reiners, P.W., Ehlers, T.A., Garver, J.I., Mitchell, S.G., Montgomery, D.R., Vance, J.A., Nicolescu, S., 2002. Late Miocene exhumation and uplift of the Washington Cascade Range. Geology 30, 767-770.

Retallack, G.J., 2004. Late Miocene climate and life on land in Oregon within a context of Neogene global change. Palaeogeography Palaeoclimatology Palaeoecology 214, 97-123.

Robichaux, R., 1980. Chapter 3. Geologic history of the riparian forests if California, in: Sands, A. (Ed.), Riparian Forests in California: Their Ecology and Conservation. Division of Agricultural Sciences, University of California, University of California, Davis.

Ruefenacht, B., Finco, M.V., Nelson, M.D., Czaplewski, R., Helmer, E.H., Blackard, J.A., Holden, G.R., Lister, A.J., Salajanu, D., Weyermann, D., Winterberger, K., 2008. Conterminous U.S. and Alaska Forest Type Mapping Using Forest Inventory and Analysis Data. Photogrammetric Engineering \& Remote Sensing 74, 1379-1388.

Strackee, J., Jansma, E., 1992. The statistical properties of 'mean sensitivity'- a reappraisal. Dendrochronologia 10, 121-135.

Taggart, R.E., Cross, A.T., 1990. Plant Successions and Interruptions in Miocene Volcanic Deposits Pacific Northwest, Lockley, M. G. and a. Rice, pp. 57-68. 
Taylor, E.L., Ryberg, P.E., 2007. Tree growth at polar latitudes based on fossil tree ring analysis. Palaeogeography, Palaeoclimatology, Palaeoecology 255, 246-264.

U. S. Geological Survey, 1999. Digital representation of "Atlas of United States Trees" by Elbert L. Little, Jr.

Utescher, T., Bruch, A.A., Erdei, B., Francois, L., Ivanov, D., Jacques, F.M.B., Kern, A.K., Liu, Y.S., Mosbrugger, V., Spicer, R.A., 2014. The Coexistence Approach-Theoretical background and practical considerations of using plant fossils for climate quantification. Palaeogeography Palaeoclimatology Palaeoecology 410, 58-73.

van den Dool, H., Huang, J., Fan, Y., 2003. Performance and analysis of the constructed analogue method applied to US soil moisture applied over 1981-2001. Journal of Geophysical Research 108, 1-16.

Wigley, T.M.L., Briffa, K.R., Jones, P.D., 1984. On the average value of correlated time series, with application in Dendroclimatology and Hydrometeorology. Journal of Climate and Applied Meteorology 23, 201-213.

Yamaguchi, D.K., Grissino-Mayer, H.D., 1993. Comment on "Resolving volcanic activity of 20 MA ago with relative accuracy of 1 YR from tree rings of petrified wood". Geophysical Research Letters 20, 2279-2280.

Yao, Z.Q., Liu, L.J., Zhang, S., 1994. Permian Wood from Western Henan, China - Implications for Paleoclimatological Interpretations. Review of Palaeobotany and Palynology 80, 277290.

Zhang, Y.G., Pagani, M., Liu, Z., Bohaty, S.M., DeConto, R., 2013. A 40-million-year history of atmospheric CO2. Philosophical Transactions of the Royal Society a-Mathematical Physical and Engineering Sciences 371. 


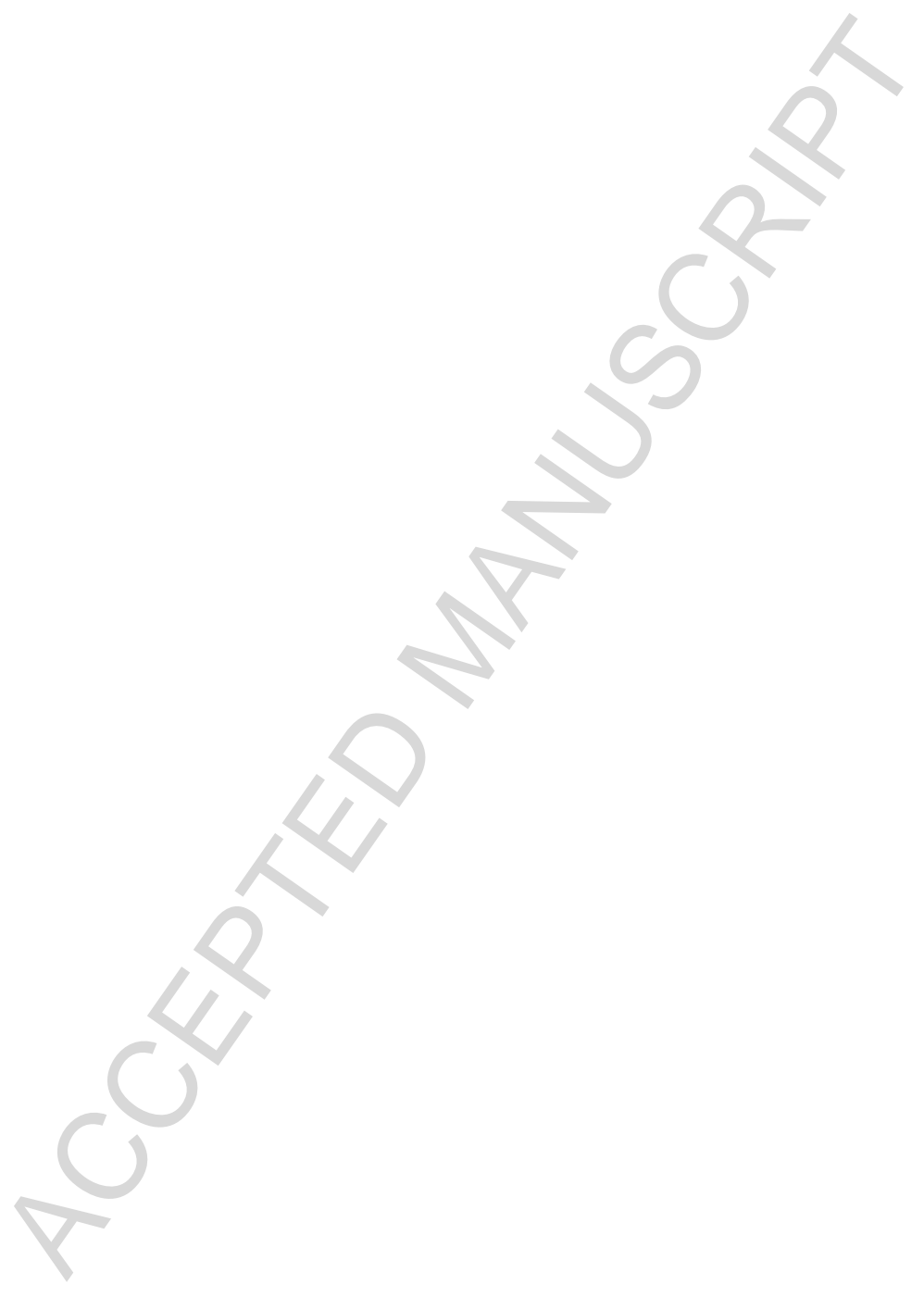




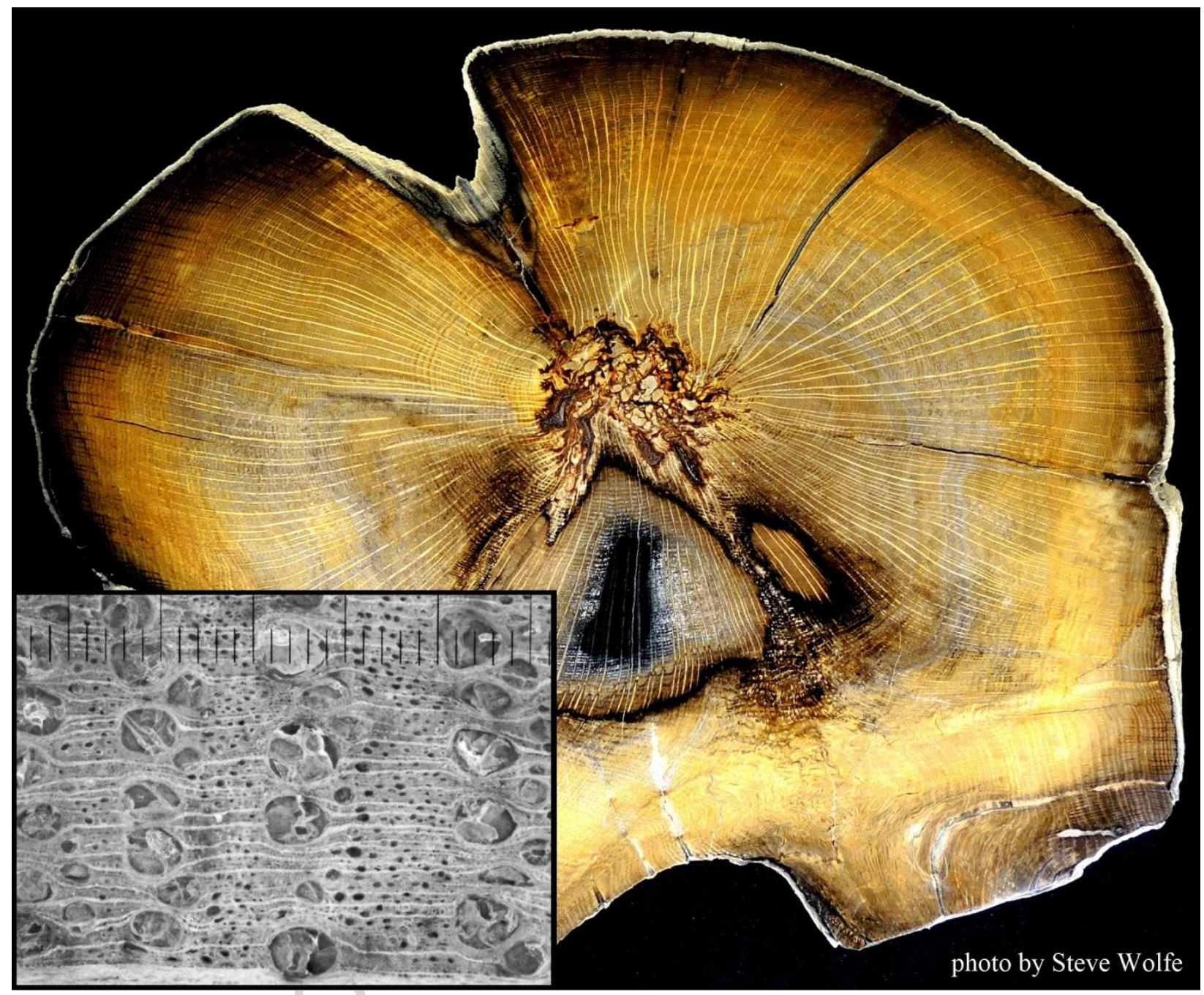

Fig. 1 (Foreground) Photomicrograph of SW Quercus tree rings. The large vessels mark the beginning of each growing season, the direction of growth being left to right in this image. Note the scale with markings of $0.1 \mathrm{~mm}$. (Background) A polished cross-section of SW Quercus, commonly called "Golden Oak" because of the appearance. 


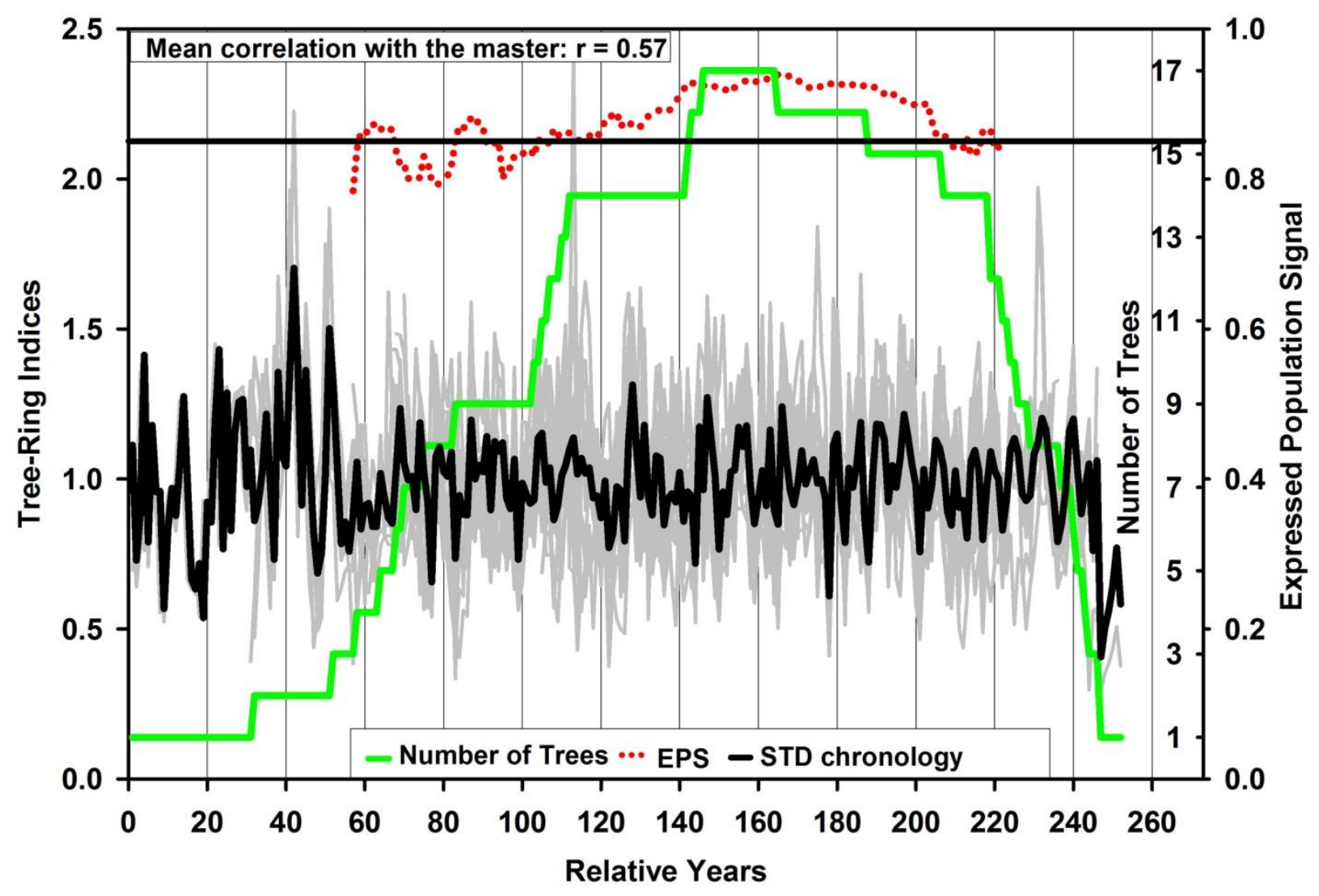

Fig. 2 Plot of statistically crossmatched ring width time series from SW Quercus. Individual ring width time series are represented by the grey lines. The mean of the individual time series is presented as a black line. Sample depth through time is indicated by the green stepped line. Signal reliability as compared with a hypothetically perfect mean time series, the Expressed Population Signal (e.g. Cook and Kairiukstis, 1990), is presented as a 50-year running value (red dotted line). Strong reliability is indicated when the red dotted line is higher than the black horizontal line. 


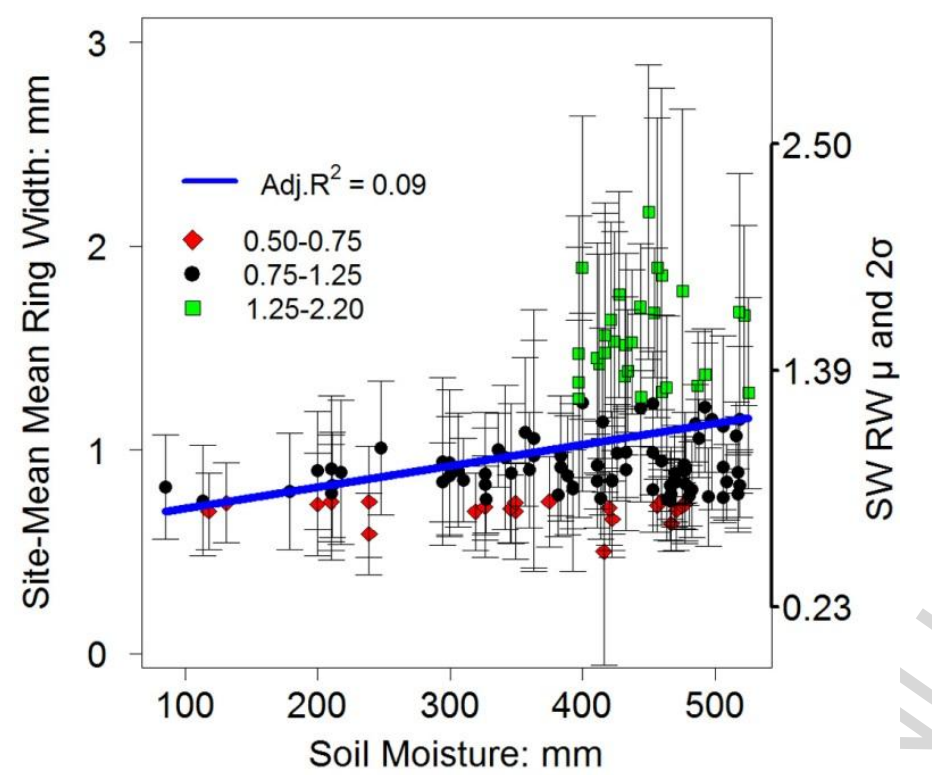

Fig. 3a Regression of modern Quercus site-mean time series ring widths on the estimated annual soil moisture. The distribution of modern Quercus site-mean timeseries ring widths are divided into three groups as indicated by the legend. The $2 \sigma$ ranges for the mean ring width values from the individual time series at each site are indicated by the vertical bars. The site-mean and $2 \sigma$ range for the individual SW time series ring widths are indicated on the righthand y-axis with a horizontal bar marking the position of the SW site-mean relative to the modern ring width distributions. The modeled soil moisture best matches observed values for a 1.3 meter column of soil (Huang et al., 1996). 


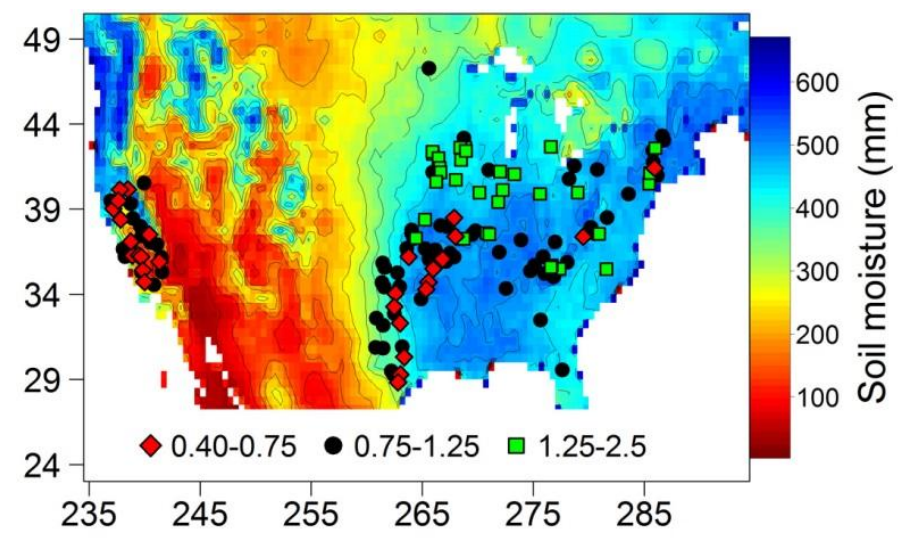

Fig. 3b Geographic distribution of Quercus sites and their site-mean ring width values plotted on estimates of the 12-month (January-December) monthly mean soil moisture. The modeled soil moisture best matches observed values for a 1.3 meter column of soil (Huang et al., 1996). The partitions and ranges for the ring widths are the same as in Figure $3 \mathrm{a}$.

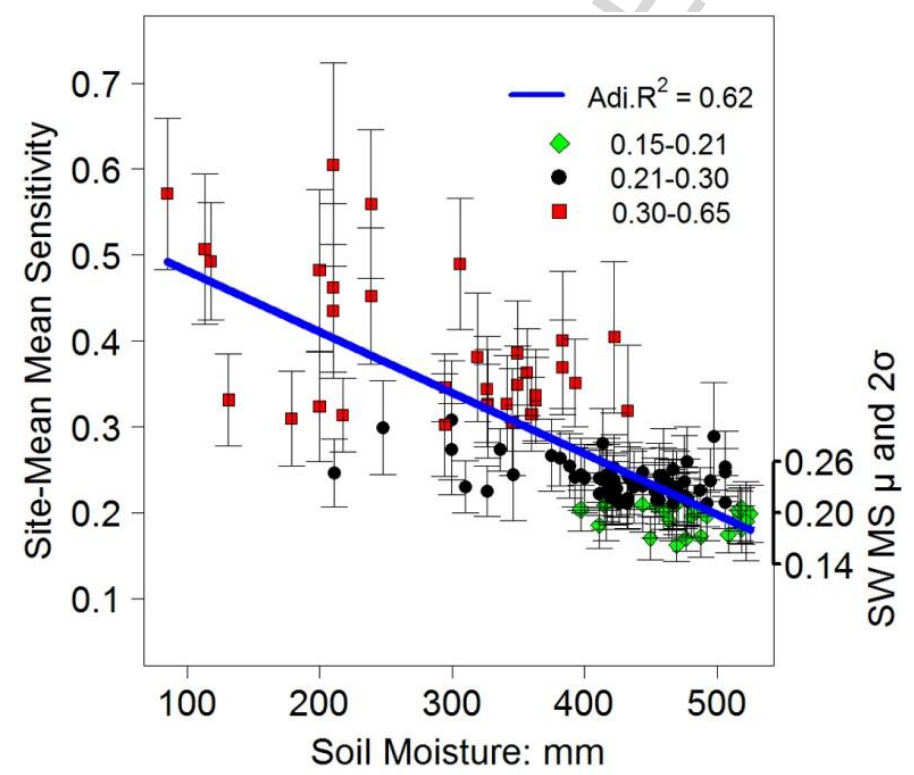

Fig. 4a Regression of site-mean values for mean sensitivity based on the mean sensitivity of the individual ring width time series. The overall distribution is partitioned into three parts represented by the symbols and ranges indicated in the legend.The horizontal line indicates the 
placement of the SW site-mean amoung the modern site-mean values. The modeled soil moisture best matches observed values for a 1.3 meter column of soil (Huang et al., 1996).

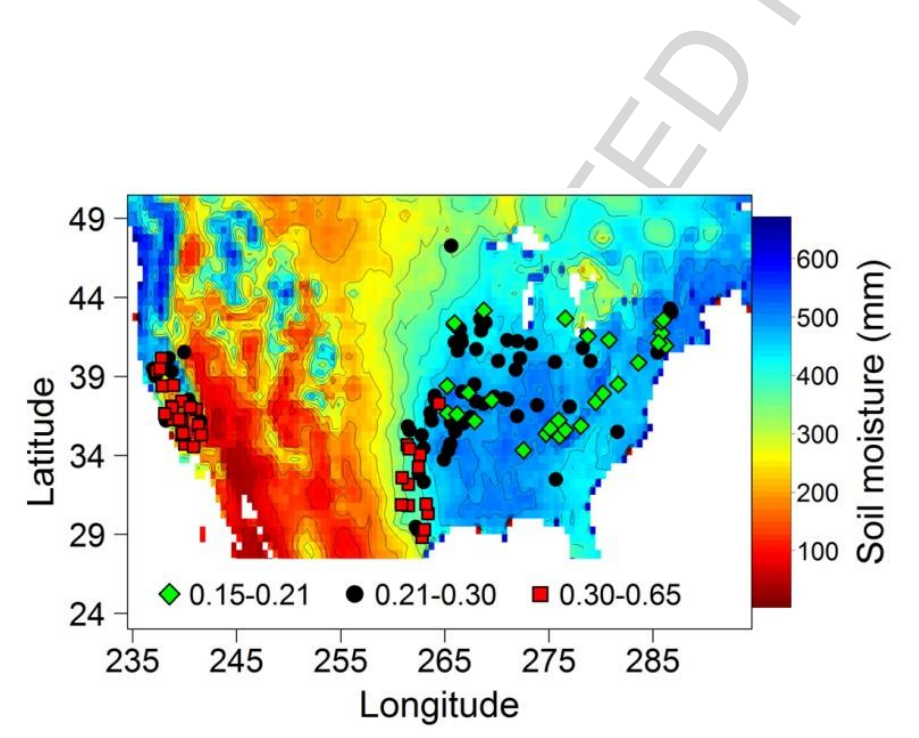

Fig. 4b Geographic distribution of Quercus sites and their site-mean mean sensitivity values plotted on estimates of the 12-month (January-December) monthly mean soil moisture. The partitions and ranges for the mean sensitivity are the same as in Figure 4a. The modeled soil moisture best matches observed values for a 1.3 meter column of soil (Huang et al., 1996). 


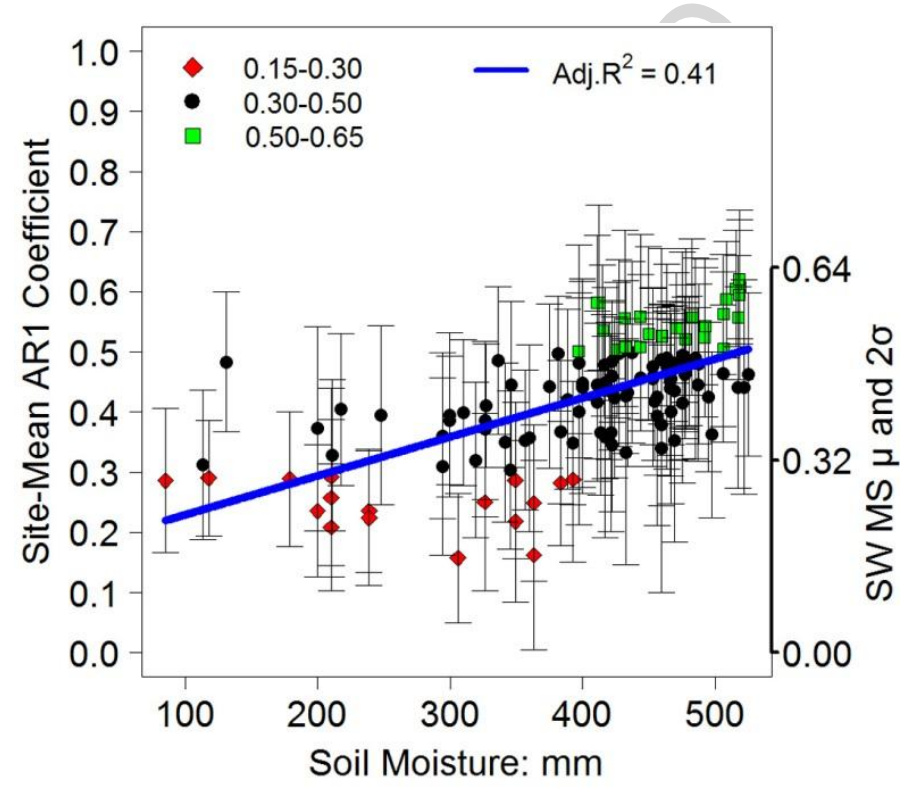

Fig. 5 Regression of site-mean values for AR1 on annual monthly mean soil moisture. The overall distribution is divided into three parts represented by the symbols and ranges indicated in the legend.The mean $(\sigma)$ and $2 \sigma$ range for the Stinking Water AR1 are presented on the right hand $y$ axis, with a horizontal bar marking the position of the SW site-mean relative to the 
modern distributions. The modeled soil moisture best matches observed values for a 1.3 meter column of soil (Huang et al., 1996).

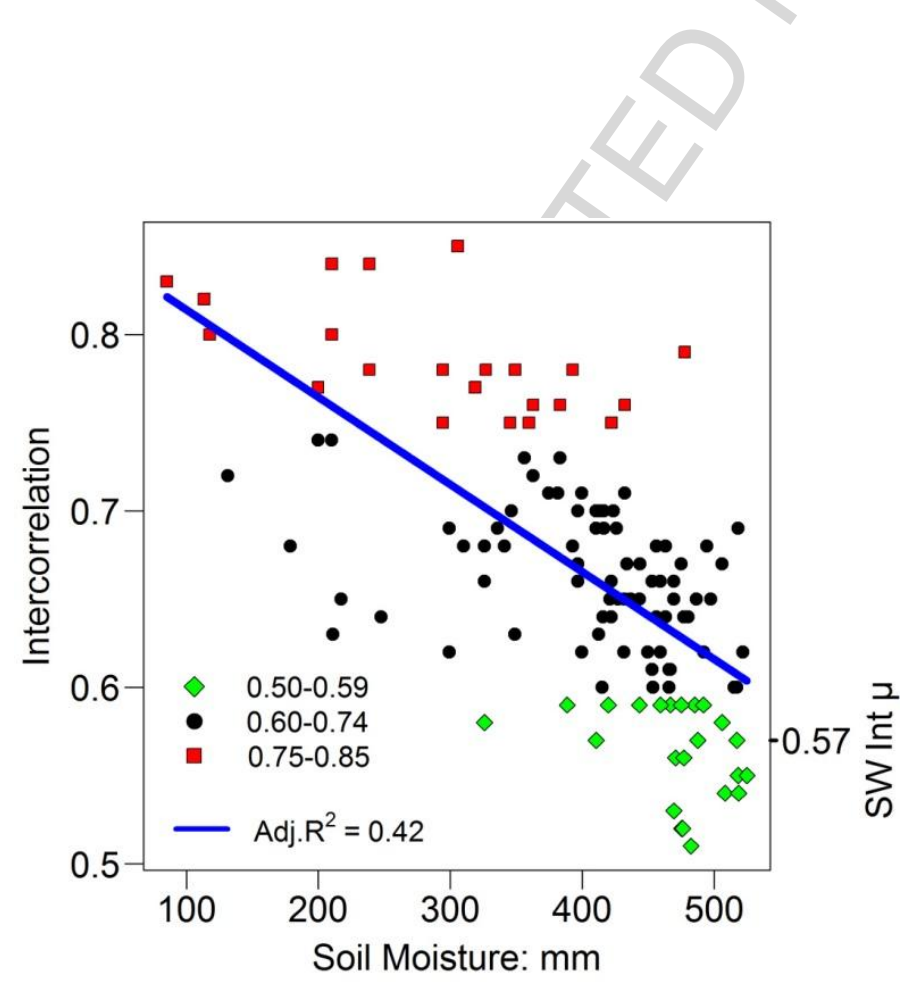

Fig 6a Regression of site-mean values for intercorrelation on the annual monthly mean soil moisture. The overall distribution is divided into three parts represented by the symbols and ranges indicated in the legend. The mean $(\sigma)$ for the Stinking Water autocorrelation is presented 
on the right hand y axis, with a horizontal bar marking the position of the SW site-mean relative to the modern distributions. The modeled soil moisture best matches observed values for a 1.3 meter column of soil (Huang et al., 1996).

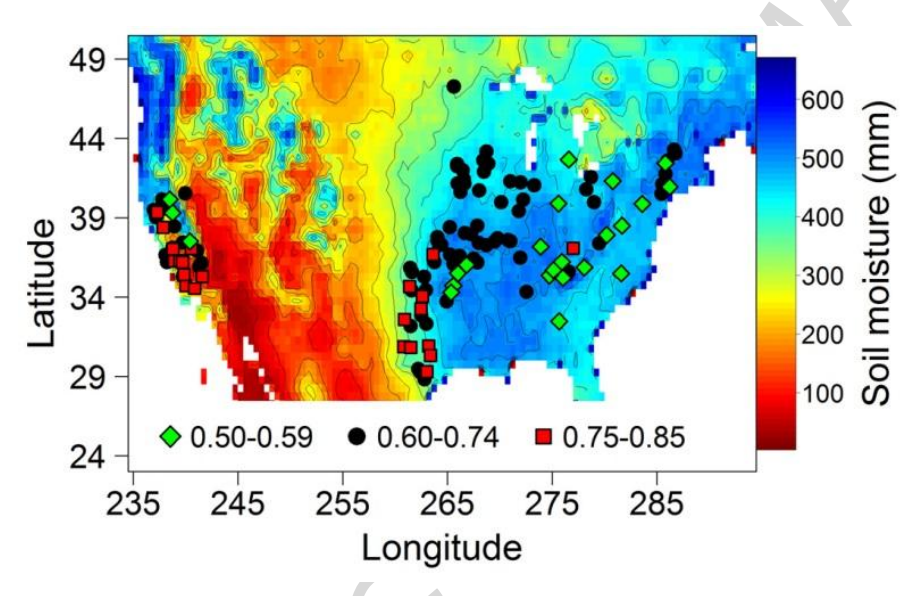

Fig. 6b Geographic distribution of Quercus sites and their site-mean intercorrelation values plotted on estimates of the 12-month (January-December) monthly mean soil moisture. The partitions and ranges for the ring widths are the same as in Figure 6a. The modeled soil moisture best matches observed values for a 1.3 meter column of soil (Huang et al., 1996). 


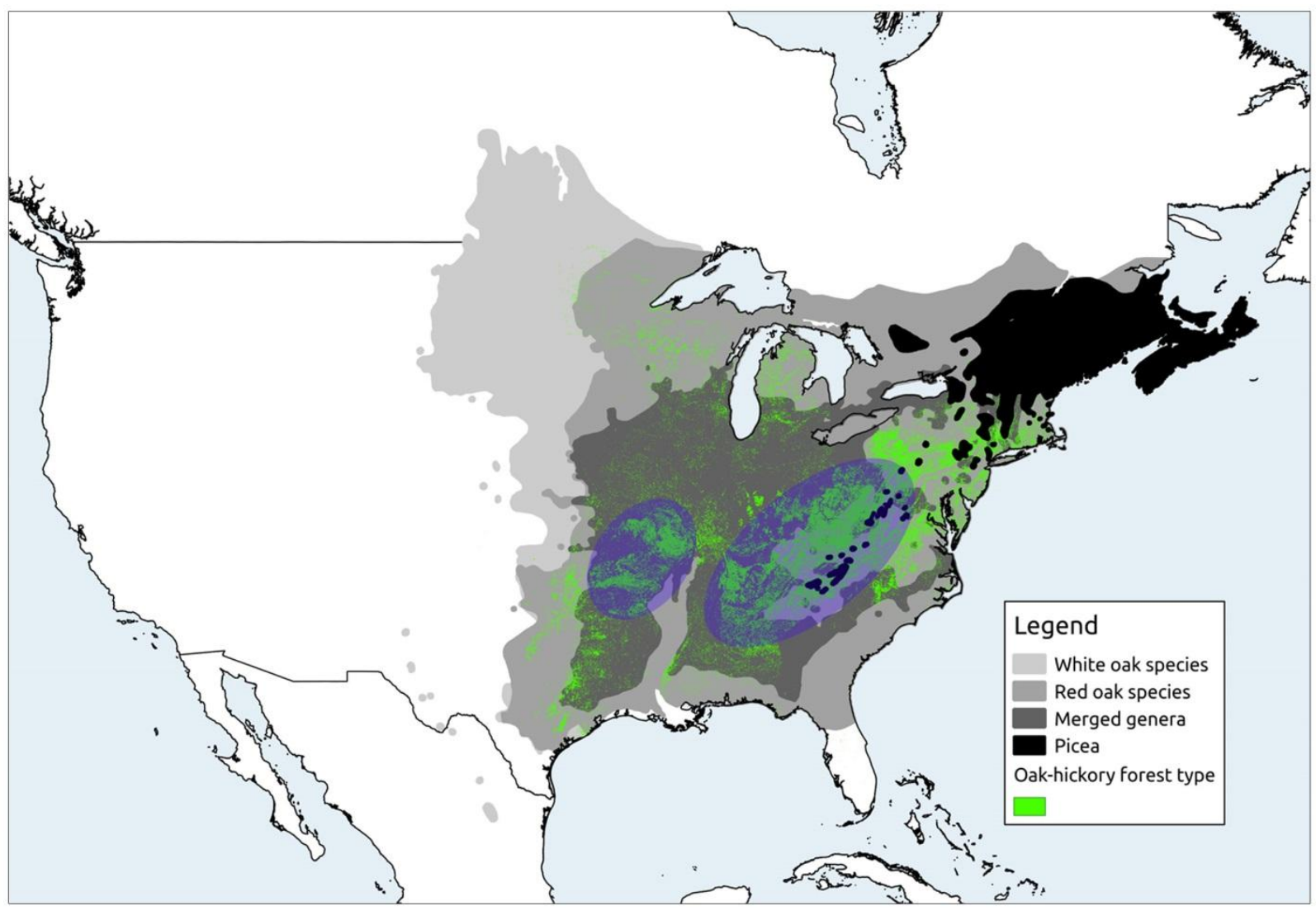

Fig. 7 Modern distributions of the tree genera present at the Stinking Water site and consistent with the mesic growing conditions indicated by the statistical comparison, and the locations of the modern Oak-Hickory Forest Type group. Quercus species in the Red Oak group and White Oak group are presented separately. The distributions of 5 other genera present at the Stinking Water site were merged based on co-occurrence. Note that the "Merged Genera" distribution covers a very large region. Picea is presented separately, because the distribution shows little overlap with the other genera. The blue ovals indicates the regions where (1) the Oak-Hickory forest type is the most common (where Quercus is the dominant genus), (2) where the OakHickory forest type overlaps with the distribution of most of the other genera present at the SW site. 


\section{Appendix 1.}

Table 1. SW tree-ring width time series lengths and cross-correlation values from COFECHA output, using the default settings for detrending. Identical superscript numbers indicate samples from the same original log. ' $r$ ' = correlation coefficient.

\begin{tabular}{|c|c|c|c|c|c|c|c|c|}
\hline Series ID & Rings & $\overline{\mathrm{r}}$ & Series ID & Rings & $\overline{\mathrm{r}}$ & Series ID & Rings & $\mathrm{r}$ \\
\hline$\overline{\mathrm{DM}} 1$ & 158 & 0.58 & WW $1 \mathrm{a}^{2}$ & 127 & 0.60 & ER $1 \mathrm{Ha}^{4}$ & 99 & 0.51 \\
\hline ZM $1057^{1}$ & 138 & 0.49 & $\mathrm{WW} 1 \mathrm{~b}^{2}$ & 141 & 0.61 & ER $1 \mathrm{Hb}^{4}$ & 98 & 0.47 \\
\hline ZM 1272 & 114 & 0.55 & $N W 2 a$ & 131 & 0.54 & ER $2 \mathrm{La}^{4}$ & 181 & 0.58 \\
\hline TM 517a & 107 & 0.50 & WW 3a & 101 & 0.58 & ER $2 \mathrm{Ha}^{4}$ & 113 & 0.57 \\
\hline TM 546a & 162 & 0.51 & $\mathrm{WW} 4 \mathrm{a}^{3}$ & 191 & 0.62 & SW $1 b^{5}$ & 204 & 0.63 \\
\hline DM 2 & 106 & 56 & $\mathrm{WW} 4 \mathrm{~b}^{3}$ & 188 & 0.60 & BE 1 & 115 & 0.66 \\
\hline RM 1272a & 166 & 0.53 & SW $2 b^{5}$ & 180 & 0.58 & SW $2 c^{5}$ & 129 & 0.54 \\
\hline WW 68 & 97 & 0.54 & GC $1 a^{6}$ & 121 & 0.59 & GC $1 b^{6}$ & 155 & 0.50 \\
\hline $\mathrm{WW} \mathrm{Wa}^{7}$ & 141 & 0.62 & $\mathrm{WW} \mathrm{Wb}$ & 149 & 0.61 & Tree Mean & 141 & 0.57 \\
\hline
\end{tabular}


Table 2. Comparison of SW locality mean and modern Quercus median site-mean ring width time series statistics. Q. alba grows in dry-mesic to mesic environments in the eastern Unites States. Q. Douglasii is a drought adapted California oak that grows in a Mediterranean climate with very dry summers. Definitions: $\overline{y r}=$ site-mean ring number; $\overline{r w}=$ site-mean average ring width; $\bar{\zeta}=$ site-mean ring width mean sensitivity; $\bar{\sigma}=$ site-mean ring width standard deviation; $\bar{G}=$ site-mean Gini coefficient; $\bar{\phi}=$ site-mean first order autocorrelation; $\bar{r}=$ site-mean intercorrelation. All the site-mean statistics are the averages of the statistical values calculated for each time series at each site.

\begin{tabular}{|c|c|c|c|c|c|c|c|}
\hline & & $\overline{r w}$ & $\zeta$ & $\sigma$ & $\mathrm{G}$ & $\phi$ & $\bar{r}$ \\
\hline SW individual & 139 & $1.40 \mathrm{~mm}$ & 0.20 & 0.22 & 0.12 & 0.32 & 0.57 \\
\hline $\begin{array}{l}\text { Modern median of site } \\
\text { means }(\mathrm{N}=126)\end{array}$ & 187 & $1.01 \mathrm{~mm}$ & 0.26 & 0.33 & 0.18 & 0.36 & 0.64 \\
\hline $\begin{array}{l}\text { Q. alba median of } \\
\text { site means }(\mathrm{N}=48)\end{array}$ & 201 & $1.26 \mathrm{~mm}$ & 0.22 & 0.30 & 0.16 & 0.39 & 0.60 \\
\hline $\begin{array}{l}\text { Q. douglasii median } \\
\text { of site means }(\mathrm{N}=29)\end{array}$ & 177 & $0.77 \mathrm{~mm}$ & 0.37 & 0.41 & 0.23 & 0.29 & 0.70 \\
\hline
\end{tabular}




\section{Highlights}

- the first statistically significant matching of many ring width time series from petrified wood

- Indication of a reliable annual climate signal and stand-level statistics for the MidMiocene

- Modern/Miocene tree ring statistic comparison indicates a mesic Mid-Miocene environment

- Modern analogue environments indicated using a Modified Coexistence Approach

- Mid-Miocene MAT and MAP indicated based on identification of modern analogue environments 